\title{
UNDERSTANDING PRECAMBRIAN KOMATIITE PETROCHEMISTRY FROM TALC BODIES WITHIN THE ILESHA SCHIST BELT, SOUTHWESTERN NIGERIA
}

\author{
*Afolabi, O. A., ${ }^{1}$ Oduneye, O. C. ${ }^{1}$ Olatunji, A. S. ${ }^{2}$ and Ajibade, A. C. ${ }^{3}$ \\ ${ }^{1}$ Department of Earth Sciences, Ladoke Akintola University of Technology, Ogbomoso \\ ${ }^{2}$ Department of Geology, University of Ibadan, Ibadan \\ ${ }^{3}$ Department of Earth Sciences, Olabisi Onabanjo University, Ago-Iwoye, \\ *Corresponding Author's Email: oaafolabi@lautech.edu.ng \\ (Received: 7th June, 2019; Accepted: 3rd October, 2019)
}

ABSTRACT

\begin{abstract}
The nature of parentage of talc bodies from the northern part of Ilesha schist belt was investigated and compared with altered ultramafic - Komatiite. Observations from thin sections revealed altered serpentine with included nodular olivines. Talc, chlorite and tremolite were other minerals present. Geochemical analysis of five (5) rock samples taken from talc bodies outcropped from both sides of the Ifewara Shear Zone (ISZ) revealed magnesia $(\mathrm{MgO})>18 \%$ and $\mathrm{Al}_{2} \mathrm{O}_{3} / \mathrm{TiO}_{2}$ values $~ 40 . \mathrm{MgO}$ values ranged from $23.01-32.79$ wt. $\% . \mathrm{Al}_{2} \mathrm{O}_{3}$ and $\mathrm{TiO}_{2}$ values averaged 2.34 and 0.04 wt. \% respectively. $\mathrm{Mg} \#$ values $(87.93$ - 90.71) supported ultramafic precursor. Major oxide variation plots against magnesia revealed negative correlation in $\mathrm{Al}_{2} \mathrm{O}_{3}, \mathrm{TiO}_{2}$ vs $\mathrm{MgO}$. Co, $\mathrm{V}, \mathrm{Ni}$ and $\mathrm{Cu}$ concentrations were significantly higher than the incompatible elements. Maximum Ni and Co values were $1765.10 \mathrm{ppm}$ and $108.60 \mathrm{ppm}$ respectively. The rare earth element (REE) concentrations showed relative enrichment in light rare earth element (LREE). The values of $\mathrm{Gd} / \mathrm{Yb}(\mathrm{N})$ ranges from $0.94-1.86$. The $\mathrm{Gd} / \mathrm{Yb}(\mathrm{N})$ and $\mathrm{Al}_{2} \mathrm{O}_{3} / \mathrm{TiO}_{2}$ suggested that the precursor to the talc bodies were possible Gorgona group III type komatiite. Plot of V vs Ti indicated an Island arc environment for the emplacement of these talc bodies.
\end{abstract}

Keywords: Gorgona-type-Komatiite, Talc-bodies, ISZ, Serpentine, Magnesia

INTRODUCTIONTalc bodies are metamorphosed rocks with carbonate or ultramafic protoliths. The formation of talc bodies has been restricted to i) metamorphism of siliceous dolomitic carbonate rocks and ii) altered ultramafic bodies (Desmarais, 1981). Alteration of these protoliths is so intense that the products lose most evidences that may be linked to their parentage. The preservation of these protoliths, especially ultramafites in Archean/Proterozoic Cratons, is rare. This is due to the instability of ferromagnesian minerals at atmospheric conditions. Talc bodies are particularly enriched in ferromagnesian minerals. Occurrences of talc bodies have been preserved as unmetamorphosed to slightly metamorphosed ultramafic units within Cratons (Barberton greenstone belt/Swaziland Supergroup, South Africa) to metamorphosed relics of low to medium grade metamorphism within shields or mobile belts (Talc Schist within Schist belts, SW Nigeria) in Africa. Metamorphism of serpentine-rich ultramafic bodies yields chlorite-pyrophyllite-tremoliteactinolite rich talc bodies.
From the southwestern part of the Proterozoic schist belts in the Precambrian basement complex of Nigeria, south of the Trans Saharan mobile belt, several talc occurrences in Isanlu-Egbe; Ilesha and Oyan-Iseyin River belts have been reported. Olobaniyi and Mucke (2011) discussed the chromite mineralogy in talc bodies from the Egbe-Isanlu schist belt. Within the Ilesha schist belt, talc occurrences have been reported in Wonu-Apomu, Ile-Ife, Ikirun, Esa-Oke (Elueze, 1981; Akin-Ojo, 1992 Elueze and Akin-Ojo, 1993 and Bolarinwa and Adeleye, 2015)

Metamorphism of ultrabasic rocks yields the formation of talcose bodies from continued alteration of serpentines (El-Sharkawy, 2000; Olobaniyi and Mucke, 2011). The hydration of olivine rich minerals (serpentinisation) form serpentines. Preserved serpentines and relic olivine grains in talcose rocks unequivocally support ultramafic parentage. Many komatiite occurrences are described as thick volcanosedimentary units with ultramafic to mafic volcanics at the base with granite bodies having close lithostructural relationships. 
Archean greenstones occurring as komatiite bodies within narrow elongate structurally controlled troughs are probable products of decompression of hotter mantle not similar to contemporary mantle (Arndt, 2003; Sossi et al., 2016). Komatiites are, in relation to source, high magnesia rocks from high degree melting of deep seated hot mantle source (Arndt, 2003). Komatiitic units of Archean origin are described as either basaltic komatiite or peridotitic komatiite. Magnesia values for this rock type ranges from 1832 wt. \% (i.e. $>18$ wt. \%) and low alumina concentration $(<4$ wt. $\%)$ with equally low $\mathrm{CaO}$ $(<5$ wt. \%) (Gopta, 2007). Komatiites are distinguished from rocks such as meimechite (serpentinite with olivine phenocrysts), boninite (Mg-rich andesite volcanics) by $\mathrm{TiO}_{2}$ values less than 1 . These chemical characters are equally typical of Talc bodies. Two classification of komatiite have been proposed. The classification by Nesbitt and Sun (1976), Sun and Nesbitt (1978) and Nesbitt et al., 1979 described two kinds of komatiites namely: i) Al-depleted komatiite (low $\mathrm{Al}_{2} \mathrm{O}_{3} / \mathrm{TiO}_{2}$ and depleted HREE and ii) $\mathrm{Al}-$ undepleted komatiite $\left(\mathrm{Al}_{2} \mathrm{O}_{3} / \mathrm{TiO}_{2} \sim 20\right.$ and flat HREE). Jahn et al., (1982) described three groups of komatiites namely: Group I that corresponds to Nesbitt et al.'s (1979) Al-undepleted komatiites $\left(\mathrm{Al}_{2} \mathrm{O}_{3} / \mathrm{TiO}_{2} \sim 20,(\mathrm{Gd} / \mathrm{Yb}) N \sim 1\right)$, flat HREE; Group II corresponds to Al-depleted komatiite $\left(\mathrm{Al}_{2} \mathrm{O}_{3} / \mathrm{TiO}_{2} \sim 10,(\mathrm{Gd} / \mathrm{Yb}) N>1\right.$, depleted HREE) and Group III which is a compliment to Al-depleted komatiite with $\mathrm{Al}_{2} \mathrm{O}_{3} / \mathrm{TiO}_{2} \sim 40$, $(\mathrm{Gd} / \mathrm{Yb}) N<1$, enriched HREE.

Talc bodies were observed west of the NNE Ifewara shear zone (ISZ), north of the Ilesha Schist belt, southwestern Nigeria. Rahaman (1976), Elueze (1988) and Dada (2015) reported restriction of mafic lithologic units to the west of the Ifewara shear zone while the eastern divide is dominated by quartzite, quartz schist and minor amphibolite. In the current study, talc bodies were restricted to the west of this structural divide. The origin and nature of talc bodies in the Proterozoic schist belt of southwestern Nigeria has not been elucidated for petrogenetic studies. This is probably due to the intensity of alteration during metasomatism and possible simple mineralogy of talc-actinolite as earlier reported by Elueze, 1988. The geochemistry of talc rich schistose units within the Ilesha schist belt in south-western Nigeria is studied for its elemental composition, nature and petrogenesis.

\section{METHODOLOGY}

Field mapping exercise was performed to reveal lithology and relationship. Talc bodies observed were mapped and samples obtained. Samples were observed to be free from iron stains. Five representative hand specimen samples selected were pulverised and analysed for elemental concentrations at the ACME Lab, Vancouver, Canada. For major elements analysis, dried pulverised powder splits of whole-rock samples were mixed with lithium tetraborate/metaborate flux followed by fusion and casting into glass discs, then analyzed. Trace, rare earth and refractory elements determined by inductively coupled plasma-mass spectrometry (ICP-MS) following a $\mathrm{LiBO}_{2} / \mathrm{Li}_{2} \mathrm{~B}_{4} \mathrm{O}_{7}$ fusion (method LF100, Bureau Veritas Commodities Canada Ltd.). Moisture and loss on ignition (LOI) were determined separately at $105^{\circ} \mathrm{C}$ and $1000{ }^{\circ} \mathrm{C}$. For classifications such as the Total Alkali Vs Silica, concentrations were recalculated to $100 \%$ freeing $\mathrm{CO}_{2}$ and $\mathrm{H}_{2} \mathrm{O}$.

\section{RESULTS \\ Geological setting}

Talc rich bodies within the northern end of the Ilesha schist belt (Sheet $243 \mathrm{NE}$, Ilesha) in southwestern part of the Precambrian Basement complex of Nigeria occur as small lenticular to sub-circular to ovoid discrete mappable units (Fig.1). In the study area talc bodies generally occurred as low lying lenticular to sub-circular outcrops. Field evidences revealed occurrences are in close association with quartzite and quartz schist. During the field mapping, talc bodies were observed localised within two locations: Ilua, southwest of the area and Kajola, north-central of the area. Both locations were found west of the Ifewara Shear Zone (ISZ). The Kajola location is closer to the shear zone than the Ilua outcrops. Exposures in the western divide of the Ifewara shear zone (ISZ) were observed as low lying unit. At the base of the narrow quartzite ridge at Ilua, southwest of the impressive granite batholith were found whitish-greenish talcose rocks. Talc 
bodies at Kajola, closer to the Ifewara shear zone (ISZ), are exposed as whitish - greenish mounds (Fig.2).

Greasy feel from touch and hardness less than 2.5 on the Mohs scale of hardness are basic characteristics of talc. The samples of the study displayed these properties. Hand specimen revealed several rusty stains implying presence of ores. Mineral identification from transparent light microscopy revealed chlorite (Ch), talc (Tc), tremolite (Tl), serpentine (S) and opaque minerals. Serpentine revealing spinifex texture and playing host to restite olivine nodules (Fig.3a-b) occurring in accessory amounts show evidence for steatization (formation of talc). The association of chlorite and talc suggest greenschist facies implicating low temperature metamorphism. Polished thin section analysis revealed chalcopyrite $\left(\mathrm{CuFeS}_{2}\right)$, with higher relief than the surrounding chlorite - talc acicular grains, as the dominant opaque minerals (Fig.3c) occurring as disseminated ore fluids exsolved possibly during steatization (eq.1). Altered serpentines are associated with the formation of talc, chlorite, tremolite and vermiculite. Other rocks closely associated with talc bodies include quartzite and quartz schist.

$2 \mathrm{Mg}_{3} \mathrm{Si}_{2} \mathrm{O}_{5}(\mathrm{OH})_{4}+4 \mathrm{SiO}_{2} \quad 2 \mathrm{Mg}_{3} \mathrm{Si}_{4} \mathrm{O}_{10}(\mathrm{OH})_{4}+$ $2 \mathrm{H}_{2} \mathrm{O}$..........eq. 1

Serpentine

Talc

Quartzite formed the impressive ridge, Effon Psammite ridge. The ridges formed structural highs that trend in the NE direction. Heights of these ridges reached 2100 feet and show evidence of uplift with an east dipping limbs that describe the ridges as homoclines (Afolabi, 2017). Quartz blocks of variable sizes ranging from $40 \mathrm{~cm} x$ $20 \mathrm{~cm}$ to $75 \mathrm{~cm} \times 30 \mathrm{~cm}$ are separated by two joints, predominantly. Each block is separated by thin lamellae of muscovite-quartz rich schistose material giving the rock a schistose appearance. The quartzite lie unconformably over the gneisses with field evidences supporting that the quartzite ridges were thrust onto the gneisses. The quartz schist occupies about $50 \%$ of the entire surface area of the study. It is composed of quartz and muscovite as the dominant minerals. 


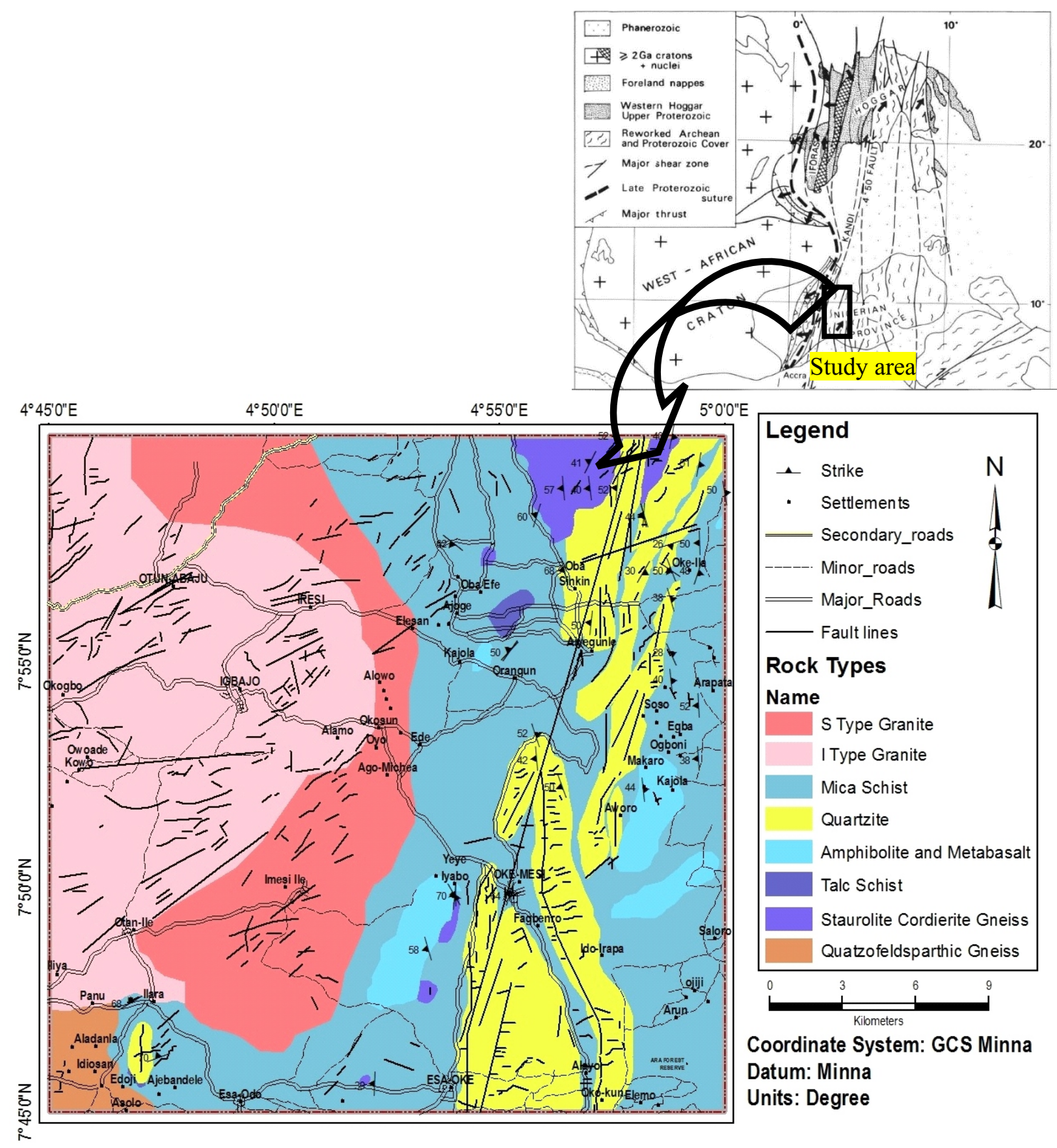

Figure 1. Geological map of the NE Ilesha Sheet 243 (Afolabi, 2017). Top right is the geological map of Western Africa (adapted after Caby, 1989). 


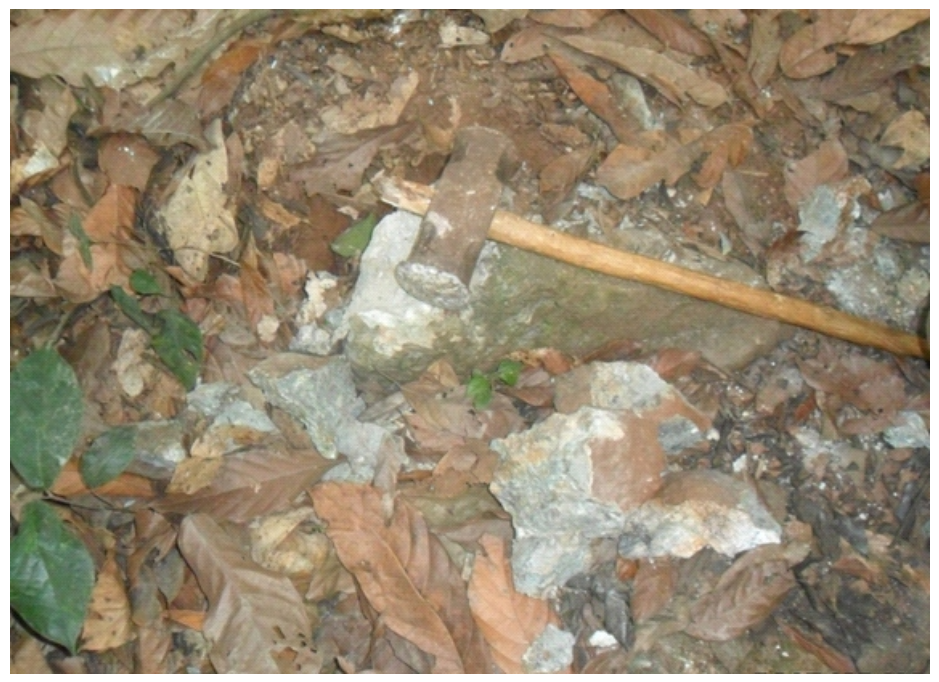

Figure 2: Talc schist at Ilua located at the southwestern part of the study area.
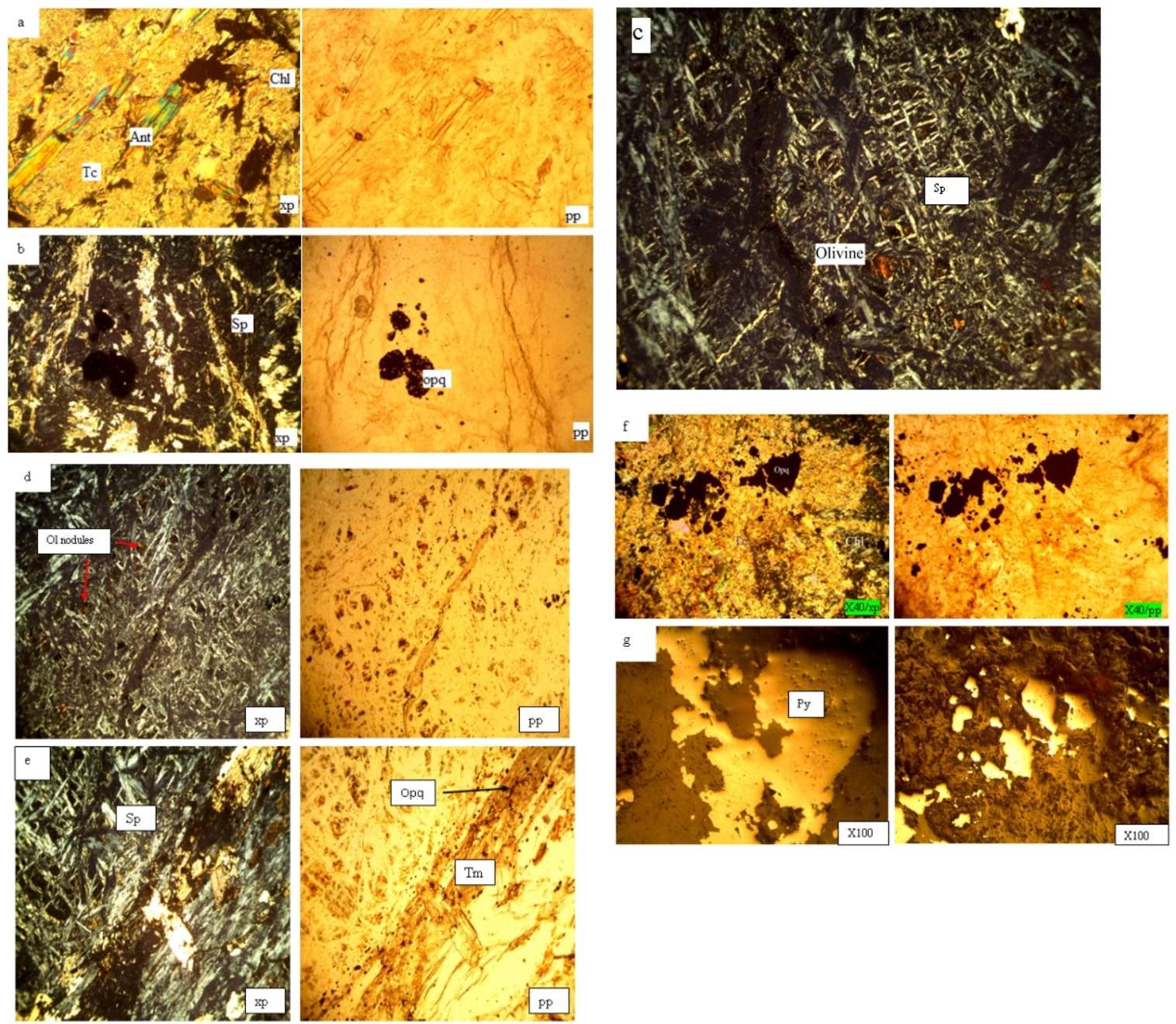

Figure 3: a) Talc (Tc), chlorite (Chl) and anthophylite (Ant). b) opaque (Opq) minerals, possibly exsolved by-product from serpentinization, are set in altered serpentine (Sp) revealing spinifex texture. c) Serpentine (Sp) hosting nodules of golden olivine crystals describe a spinifex texture with skeletal serpentine with olivine restite occurring as interstitial grains. d) Serpentine (Sp) relics display spinifex texture. (e) Golden crystallites of restite olivine (Ol) crystallite are closely associated with opaque (Opq) mineral, possibly chromite nodules trailing tremolite (Tm) fibres. f) Polished thin section of Talc schist from Ilua under transmitted light revealed large grains of opaque minerals. (g) Under reflected light the opaque minerals are pyrite (Py) and chalcopyrite with evidence supporting exsolution from alteration reactions. (Photomicrograph is cross nicol and magnification is $\mathrm{x} 40)$. 


\section{Geochemistry of the Talc bodies}

The few outcropped talc bodies on both sides of the Ifewara Shear Zone (ISZ) were small in dimension and mostly weathered. Five representative fresh hand specimen samples of talc bodies selected were analysed to reveal its geochemistry. Five representative samples were obtained from two locations where the talc bodies outcropped. Major oxide geochemistry of the talc bodies is presented in Table 1 as weight percentage (wt. \%) normalised to $100 \%$. Silica $\left(\mathrm{SiO}_{2}\right)$ composition varies from 43.12 wt. \% to 57.52 wt. $\%$ with 50.45 wt. $\%$ as the average silica composition. $\mathrm{SiO}_{2}$ values from the result exceeded 42 wt. \% which is the limit for ultrabasic rocks. With exception of samples STB1 and 3, $\mathrm{SiO}_{2}$ values of the study compared well with $\mathrm{SiO}_{2}$ values for Komatiites from Barberton, 47.7 (Viljoen and Viljoen, 1969b and 1982 and Abitibi, 45.9 (Lahaye et al., 1995). These values fell with the basalt to andesite limits, $42-55$ wt. $\%$, suggesting metamorphism, alteration or contamination. Alumina values were very low and did not exceed $5.00 \mathrm{wt} . \%$. The concentration of alumina ranged from $0.97-4.81 \mathrm{wt} . \%$ with mean value of $2.34 \mathrm{wt} . \%$.

Talc bodies are typically enriched in magnesia for which a classification of komatiites is based. Komatiites with less than 18 wt. \% magnesia is classed as 'Basaltic Komatiite" and komatiite with magnesia $>18 \mathrm{wt} . \%$ is called 'Peridotitic Komatiite'. Concentration of magnesia ranged from $23.01 \mathrm{wt} . \%$ to $32.79 \mathrm{wt} . \%$ with a mean value of 29.29 wt. \%. Lime $(\mathrm{CaO})$ values are quite low. The values for $\mathrm{CaO}$ did not exceed 0.05 wt. $\%$ except for sample STB3 having a concentration of 5.89 wt. \%. Values for $\mathrm{CaO}$ ranged from $0.20-$ 5.89 wt. $\%$ with a mean value of 1.20 wt. $\%$. Mean value calculated excluding sample STB3 is $0.03 \mathrm{wt}$. $\%$ this is a result of concentration of lime $(\mathrm{CaO})$ in the talc bodies (Table 1). Values for oxide of manganese $(\mathrm{MnO})$ are observed to be generally higher than those recorded for $\mathrm{CaO}$. Mean value for manganese oxide $(\mathrm{MnO})$ is $0.10 \mathrm{wt} . \%$ and is calculated from values ranging from $0.07-0.13$ wt. $\%$.
With low values observed for alumina, similarly low concentrations were observed for the alkali elements. Values of some samples STB2, 4 and 5 fell below detection limit for soda $\left(\mathrm{Na}_{2} \mathrm{O}\right)$ while samples STB3, 4 and 5 fell below detection limit for potash $\left(\mathrm{K}_{2} \mathrm{O}\right) \cdot \mathrm{Na}_{2} \mathrm{O}$ values for samples STB1 and 3 are 0.02 and 0.05 respectively while $\mathrm{K}_{2} \mathrm{O}$ values observed for samples STB1 and 2 were 0.04 and 0.02 respectively. $\mathrm{P}_{2} \mathrm{O}_{5}$ values were below detection limit except samples STB1 (0.02) and STB5 (0.05) (Table 1). Ti, used in characterisation of komatiite, were observed for all samples. Oxide of titanium $\left(\mathrm{TiO}_{2}\right)$ had a minimum value of 0.02 wt. $\%$ and a maximum value of 0.07 wt. $\%$. The mean value at $0.04 \mathrm{wt} . \%$ is below $1 \%$.

\section{Trace element geochemistry of the Talc Schist}

Trace element composition for the talc Schist, presented in Table 2 , revealed very low values for incompatible elements while enrichment in compatible elements is favoured. The high field strength elements (HFSE) showed low concentrations in zirconium $(\mathrm{Zr})$, niobium $(\mathrm{Nb})$ and tantalum $(\mathrm{Ta}$ ) while hafnium (Hf) could not be detected. Similarly, large ion trace elements (LILE) revealed concentration values for barium $(\mathrm{Ba})$, rubidium ( $\mathrm{Rb})$, strontium $(\mathrm{Sr})$ and lead $(\mathrm{Pb})$. However, high values were recorded for cobalt $(\mathrm{Co})$, vanadium $(\mathrm{V})$ and especially nickel $(\mathrm{Ni})$.

Zirconium $(\mathrm{Zr})$ values ranged from $0.6-2.20$ ppm, niobium $(\mathrm{Nb})$ ranged from $0.3 \mathrm{ppm}$ to 1.5 ppm. $\mathrm{Nb}$ value for sample STB2 fell below detection limit. Representative average values of $1.04 \mathrm{ppm}$ and $0.55 \mathrm{ppm}$ were calculated respectively for $\mathrm{Zr}$ and $\mathrm{Nb}$. Only two samples, STB1 (0.1 ppm) and 3 (0.2 ppm), revealed concentration values for tantalum (Ta). The fluid mobile elements (LILE) have low concentrations for barium $(\mathrm{Ba})$, rubidium $(\mathrm{Rb})$ and strontium $(\mathrm{Sr})$. The highest value recorded for barium $(\mathrm{Ba})$ is $23.00 \mathrm{ppm}$ (STB2) and its lowest is $1.00 \mathrm{ppm}$ (STB3). The mean value for $\mathrm{Ba}$ is $9.00 \mathrm{ppm}$. Average rubidium $(\mathrm{Rb})$ and strontium $(\mathrm{Sr})$ values were $0.90 \mathrm{ppm}$ and $2.10 \mathrm{ppm}$ respectively calculated from $0.40-1.80 \mathrm{ppm}$ and $0.25-4.60$ ppm respectively. 
Table 1: Major oxide concentration values in wt. \% for Talc Schist

\begin{tabular}{lcccccccccc} 
Sample ID & $\mathrm{SiO}_{2}$ & $\mathrm{Al}_{2} \mathrm{O}_{3}$ & $\mathrm{Fe}_{2} \mathrm{O}_{3}$ & $\mathbf{M g O}$ & $\mathrm{CaO}$ & $\mathrm{Na}_{2} \mathrm{O}$ & $\mathrm{K}_{2} \mathrm{O}$ & $\mathrm{TiO}_{2}$ & $\mathbf{M n O}_{2}$ & $\mathbf{P}_{2} \mathrm{O}_{5}$ \\
\hline STB1 & 57.52 & 2.84 & 5.55 & 27.36 & 0.03 & 0.02 & 0.04 & 0.03 & 0.07 & 0.02 \\
STB2 & 43.12 & 0.97 & 7.70 & 32.79 & 0.04 & 0.005 & 0.02 & 0.02 & 0.10 & 0.005 \\
STB3 & 53.10 & 4.81 & 6.26 & 23.01 & 5.89 & 0.05 & 0.005 & 0.07 & 0.13 & 0.005 \\
STB4 & 49.17 & 1.70 & 7.35 & 31.31 & 0.02 & 0.005 & 0.005 & 0.04 & 0.10 & 0.005 \\
STB5 & 49.34 & 1.37 & 7.04 & 31.99 & 0.03 & 0.005 & 0.005 & 0.04 & 0.09 & 0.01 \\
\hline Min & 43.12 & 0.97 & 5.55 & 23.01 & 0.02 & 0.01 & 0.01 & 0.02 & 0.07 & 0.01 \\
Max & 57.52 & 4.81 & 7.70 & 32.79 & 5.89 & 0.05 & 0.04 & 0.07 & 0.13 & 0.02 \\
Average & $\mathbf{5 0 . 4 5}$ & $\mathbf{2 . 3 4}$ & $\mathbf{6 . 7 8}$ & $\mathbf{2 9 . 2 9}$ & $\mathbf{1 . 2 0}$ & $\mathbf{0 . 0 2}$ & $\mathbf{0 . 0 2}$ & $\mathbf{0 . 0 4}$ & $\mathbf{0 . 1 0}$ & $\mathbf{0 . 0 1}$ \\
\hline
\end{tabular}

Table 2. Trace element concentration in parts per million ( $\mathrm{ppm}$ ) for the Talc Schist

\begin{tabular}{lcccccccc}
\hline Sample ID & STB1 & STB2 & STB3 & STB4 & STB5 & Min & Max & Average \\
\hline \hline $\mathrm{Ba}$ & 10 & 23 & 1 & 8 & 3 & 1 & 23 & 9 \\
$\mathrm{Co}$ & 67.8 & 108.6 & 63.6 & 95 & 91.5 & 63.6 & 108.6 & 85.3 \\
$\mathrm{Ga}$ & 4.7 & 1.5 & 5 & 2.4 & 1.6 & 1.5 & 5 & 3.04 \\
$\mathrm{Nb}$ & 0.5 & 0.05 & 1.5 & 0.4 & 0.3 & 0.05 & 1.5 & 0.55 \\
$\mathrm{Rb}$ & 1.8 & 1.2 & 0.5 & 0.4 & 0.4 & 0.4 & 1.8 & 0.86 \\
$\mathrm{Sr}$ & 0.9 & 3 & 4.6 & 0.25 & 1.6 & 0.25 & 4.6 & 2.07 \\
$\mathrm{Ta}$ & 0.1 & 0.05 & 0.2 & 0.05 & 0.05 & 0.05 & 0.2 & 0.09 \\
$\mathrm{~V}$ & 44 & 45 & 51 & 39 & 38 & 38 & 51 & 43.4 \\
$\mathrm{~W}$ & 8.7 & 12.8 & 14.6 & 28.6 & 12 & 8.7 & 28.6 & 15.34 \\
$\mathrm{Zr}$ & 2.2 & 0.6 & 1.1 & 0.6 & 0.7 & 0.6 & 2.2 & 1.04 \\
$\mathrm{Y}$ & 1.4 & 0.5 & 3.1 & 11.9 & 8.6 & 0.5 & 11.9 & 5.1 \\
$\mathrm{Cu}$ & 19 & 8.7 & 0.5 & 74.3 & 44.2 & 0.5 & 74.3 & 29.34 \\
$\mathrm{~Pb}$ & 2.1 & 0.05 & 0.05 & 0.2 & 0.2 & 0.05 & 2.1 & 0.52 \\
$\mathrm{Zn}$ & 5 & 16 & 7 & 13 & 15 & 5 & 16 & 11.2 \\
$\mathrm{Ni}$ & 171.3 & 1765.1 & 118.4 & 275.1 & 330 & 118.4 & 1765.1 & 531.98 \\
$\mathrm{Bi}$ & 0.1 & 0.05 & 0.3 & 0.05 & 0.2 & 0.05 & 0.3 & 0.14 \\
\hline $\mathrm{Au}(\mathrm{ppb})$ & 0.25 & 0.9 & 0.25 & 0.25 & 0.25 & 0.25 & 0.9 & 0.38 \\
\hline
\end{tabular}

Lead $(\mathrm{Pb})$ values observed for STB1, STB4 and STB5 were 2.1, 0.02 and 0.02 respectively. $\mathrm{Pb}$ values for STB2 and 3 were below detection limits. $\mathrm{Cu}$ concentration values for STB1 (19), STB4 (74.3) and STB5 (44.2) were observed to be higher than those observed for STB2 (8.7) and STB (0.5). Mean $\mathrm{Cu}$ value is $29.34 \mathrm{ppm}$. Concentration values for nickel (Ni) values ranged from 118.40 $1765.10 \mathrm{ppm}$ with a mean value of $531.98 \mathrm{ppm}$. STB2 with maximum value for nickel (Ni, 1765.10) recorded relatively lower values in $\mathrm{Cu}$. Similarly, this concentration pattern was observed for Co values. STB2 (Co, 108.6) showed the highest value. Co concentrations ranged from 63.6 - 108.6.
Average value for vanadium (V) is $43.40 \mathrm{ppm}$. Values for vanadium (V) ranged from 38.00 52.00 ppm. Mean Zinc ( $\mathrm{Zn})$ is $11.20 \mathrm{ppm}$ calculated from values ranged from $5.00-16.00$ ppm.

Rare earth element concentration for Talc Schist

Result of elemental analysis for the Rare Earth Elements (REEs) is presented in Table 3a. Chondrite normalized values (after Boynton, 1984) are presented in Table $3 \mathrm{~b}$.

Lanthanum (La) ranged from $0.40-8.00 \mathrm{ppm}$ and 
showed a mean value of $3.30 \mathrm{ppm}$. Values for cerium $(\mathrm{Ce})$ and neodymium $(\mathrm{Nd})$ reached 6.50 ppm and $9.00 \mathrm{ppm}$ each while lowest values were $0.80 \mathrm{ppm}$ and $0.15 \mathrm{ppm}$ respectively. Mean values calculated for Ce is $2.12 \mathrm{ppm}$ and $\mathrm{Nd}$ is $3.71 \mathrm{ppm}$ are lower than lower crust (Ce, 20 and $\mathrm{Nd}, 11)$ and bulk crustal composition (Ce, 43 and $\mathrm{Nd}, 20$ ) values given by Rudnick and Gao (2003). Chondrite normalised values after Boynton (1984) for $\mathrm{La}(\mathrm{N})$ were relatively higher for samples STB4 (33.9) and STB5 (25.0) and Ce $(N)$ values for STB1 (10.5) was anomalously high. Average $\mathrm{La}(N)$ value from STB1, STB2 and STB3 yielded 3.67 and $\mathrm{Ce}(N)$ values for the samples other than STB1 yielded 1.65. These average values are expected to be more representative. Normalised chondrite REE values (Boynton, 1984) for samples STB4 and STB5 from the western half of the ISZ were exceptionally higher than other samples especially above samples STB1 and STB2 collected east of the ISZ. This pattern was however not observed for $\mathrm{Ce}(N)$ (Table 3b).
Europium $(\mathrm{Eu})$ values ranged from $0.01 \mathrm{ppm}$ to $0.45 \mathrm{ppm}$ with a mean value of $0.22 \mathrm{ppm}$. Gd values ranged from $0.09-2.01$ while normalised (after Boynton, 1984) $\mathrm{Gd} N$ values ranged from $0.45-10.1$ with average value of 4.62. Normalised average $G d N$ value (4.62) after Boynton (1984) compared with Bulk crust composition (3.7) of Rudnick and Gao (2003). $\mathrm{Eu} / \mathrm{Eu}^{*}(N)$ values ranged from $0.58-2.19$ while $\mathrm{La} / \mathrm{Yb}(N)$ values ranged from $1.04-6.19$. Values of $\mathrm{Gd} / \mathrm{Yb}(\mathrm{N})$, used in komatiite grouping, showed a distinction in the samples. Samples STD1 and 2 closer to the ISZ, east of the area, had $\mathrm{Gd} / \mathrm{Yb}(N)$ values $<1$ while samples further west of ISZ had Gd/Yb(N) $>1$ (Table 4). Minimum ytterbium $(\mathrm{Yb})$ value observed is 0.08 and maximum value is 1.11 . Erbium, Er, shared 1.11 as the maximum value and 0.02 as the minimum concentration. Ratio of $\mathrm{Gd} / \operatorname{Er}(N)$ was, however, not as discriminating as $\mathrm{Gd} / \mathrm{Yb}(\mathrm{N})$.

Table 3a: Rare earth element concentration for the Talc Schist in ppm

\begin{tabular}{lcccccccccccccc} 
Sample ID & La & Ce & Pr & Nd & Sm & Eu & Gd & Tb & Dy & Ho & Er & Tm & Yb & Lu \\
\hline STB1 & 1.5 & 6.5 & 0.45 & 2.0 & 0.38 & 0.10 & 0.41 & 0.06 & 0.44 & 0.10 & 0.18 & 0.05 & 0.35 & 0.04 \\
STB2 & 0.7 & 0.8 & 0.05 & 0.15 & 0.03 & 0.01 & 0.09 & 0.005 & 0.03 & 0.01 & 0.015 & 0.01 & 0.08 & 0.005 \\
STB3 & 0.4 & 1.4 & 0.24 & 1.5 & 0.33 & 0.29 & 0.51 & 0.08 & 0.58 & 0.10 & 0.30 & 0.05 & 0.27 & 0.05 \\
STB4 & 8.0 & 1.1 & 2.28 & 9.0 & 1.84 & 0.45 & 2.01 & 0.36 & 1.95 & 0.43 & 1.11 & 0.19 & 1.11 & 0.18 \\
STB5 & 5.9 & 0.8 & 1.43 & 5.9 & 1.12 & 0.26 & 1.58 & 0.27 & 1.59 & 0.33 & 0.94 & 0.13 & 0.71 & 0.11 \\
\hline Min & 0.40 & 0.80 & 0.05 & 0.15 & 0.03 & 0.01 & 0.09 & 0.01 & 0.03 & 0.01 & 0.02 & 0.01 & 0.08 & 0.01 \\
Max & 8.00 & 6.50 & 2.28 & 9.00 & 1.84 & 0.45 & 2.01 & 0.36 & 1.95 & 0.43 & 1.11 & 0.19 & 1.11 & 0.18 \\
Average & 3.30 & 2.12 & 0.89 & 3.71 & 0.74 & 0.22 & 0.92 & 0.16 & 0.92 & 0.19 & 0.51 & 0.09 & 0.50 & 0.08 \\
\hline
\end{tabular}

Table 3b: Chondrite (CI) normalized values after Boynton (1984) for the rare earth element composition for the Talc Schist

\begin{tabular}{lcccccccccccccc} 
Sample ID & $\mathbf{L a}$ & $\mathbf{C e}$ & $\mathbf{P r}$ & $\mathbf{N d}$ & $\mathbf{S m}$ & $\mathbf{E u}$ & $\mathbf{G d}$ & $\mathbf{T b}$ & $\mathrm{Dy}$ & $\mathbf{H o}$ & $\mathbf{E r}$ & $\mathbf{T m}$ & $\mathbf{Y b}$ & $\mathbf{L u}$ \\
\hline STB1 & 6.36 & 10.50 & 5.00 & 4.32 & 2.64 & 1.83 & 2.06 & 1.70 & 1.79 & 1.81 & 1.11 & 2.27 & 2.11 & 1.63 \\
STB2 & 2.97 & 1.29 & 0.56 & 0.32 & 0.17 & 0.18 & 0.45 & 0.14 & 0.10 & 0.18 & 0.09 & 0.45 & 0.48 & 0.20 \\
STB3 & 1.69 & 2.26 & 2.67 & 3.24 & 2.29 & 5.30 & 2.56 & 2.27 & 2.36 & 1.81 & 1.85 & 2.27 & 1.63 & 2.04 \\
STB4 & 33.90 & 1.78 & 25.33 & 19.44 & 12.78 & 8.23 & 10.10 & 10.20 & 7.93 & 7.79 & 6.85 & 8.64 & 6.69 & 7.35 \\
STB5 & 25.00 & 1.29 & 15.89 & 12.74 & 7.78 & 4.75 & 7.94 & 7.65 & 6.46 & 5.98 & 5.80 & 5.91 & 4.28 & 4.49 \\
\hline Min & 1.69 & 1.29 & 0.56 & 0.32 & 0.17 & 0.18 & 0.45 & 0.14 & 0.10 & 0.18 & 0.09 & 0.45 & 0.48 & 0.20 \\
Max & 33.90 & 10.50 & 25.33 & 19.44 & 12.78 & 8.23 & 10.10 & 10.20 & 7.93 & 7.79 & 6.85 & 8.64 & 6.69 & 7.35 \\
Average & 13.98 & 3.42 & 9.89 & 8.01 & 5.13 & 4.06 & 4.62 & 4.39 & 3.73 & 3.51 & 3.14 & 3.91 & 3.04 & 3.14 \\
\hline
\end{tabular}




\section{DISCUSSION}

MineralogyField evidences and mineralogical identification showed that the talc bodies had been highly altered. Although spinifex texture was rarely observed, relict skeletal serpentine in thin sections suggested hydrothermal alterations from metasomatic alteration of olivine to form serpentines. Evidences of olivine nodules within the serpentine crystals supported the opinion of Arndt et al. (2008) for komatiitic parental magma with low viscosity and large interval between the liquidus and the temperatures at which other silicate phases appear. Presence of talc, chlorite, tremolite implied low grade metamorphism.

Normative olivine was observed for sample STB2
(Table 5) while normative orthopyroxene, hypersthene, was observed for all samples. The plot of $\mathrm{CaO} / \mathrm{Al}_{2} \mathrm{O}_{3}$ vs $\mathrm{Mg} \#$ (Fig. 4) showed samples following the olivine trend with implications for olivine alteration into possible ortho-pyroxenes. The presence of tremolite and its possible alteration may supply the $\mathrm{SiO}_{2}$ (eq.2) needed for olivine transformation to pyroxenes. Decrease in temperature and lower concentration of Al favours the formation of actinolite/tremolite and with further decrease in temperature, chlorite (Grove et al., 1999).

$\mathrm{Ca}_{2} \mathrm{Mg}_{5} \mathrm{Si}_{8} \mathrm{O}_{22}(\mathrm{OH})_{2}+4 \mathrm{CO}_{2}<==>$ $\mathrm{Mg}_{3} \mathrm{Si}_{4} \mathrm{O}_{10}(\mathrm{OH})_{2}+2 \mathrm{CaMg}\left(\mathrm{CO}_{3}\right)_{2}+4 \mathrm{SiO}_{2} \ldots .$. eq 2 Tremolite

Table 4. Elemental ratios for Talc Schist

\begin{tabular}{lccccc}
$\mathrm{Ratio}$ & STB1 & STB2 & \multicolumn{1}{c}{ STB3 } & STB4 & STB5 \\
\hline $\mathrm{Al}_{2} \mathrm{O}_{3} / \mathrm{TiO}_{2}$ & 94.67 & 48.5 & 68.71 & 42.50 & 34.25 \\
$\mathrm{Fe} / \mathrm{Fe}+\mathrm{Mg}$ & 0.17 & 0.19 & 0.21 & 0.19 & 0.18 \\
$\mathrm{Nb} / \mathrm{Ta}$ & 5.00 & 1.00 & 8.00 & 8.00 & 6.00 \\
$\mathrm{Rb} / \mathrm{Sr}$ & 2.00 & 0.40 & 0.11 & 1.60 & 0.25 \\
$\mathrm{La} / \mathrm{Yb}$ & 3.00 & 6.00 & 1.00 & 5.00 & 6.00 \\
$\mathrm{CaO} / \mathrm{Al}_{2} \mathrm{O}_{3}$ & 0.01 & 0.04 & 1.22 & 0.01 & 0.02 \\
$\mathrm{Gd} / \mathrm{Yb}(\mathrm{N})$ & 0.98 & 0.94 & 1.57 & 1.51 & 1.86 \\
$\mathrm{Ce} / \mathrm{Sm}$ & 3.977 & 7.588 & 0.987 & 0.139 & 0.166 \\
$\mathrm{Dy} / \mathrm{Yb}$ & 0.85 & 0.21 & 1.45 & 1.19 & 1.51 \\
$\mathrm{Co} / \mathrm{V}$ & 1.54 & 2.41 & 1.25 & 2.44 & 2.41 \\
$\mathrm{Y} / \mathrm{Yb}$ & 4.00 & 6.25 & 11.48 & 10.72 & 12.11 \\
$\mathrm{Zr} / \mathrm{TiO}$ & 73.33 & 30.00 & 15.71 & 15.00 & 17.50 \\
$\mathrm{Mg} \#$ & 90.71 & 89.40 & 87.93 & 89.41 & 90.00 \\
\hline
\end{tabular}

Table 5: Normative mineralogy

\begin{tabular}{lcccccccccccc}
\hline Sample Id & Apatite & Ilmenite & Orthoclase Albite & Anorthite & Corundum & Magnetite & Hematite & Diopside & Hypesthene & Quartz & Olivine \\
\hline \hline STB1 & 0.05 & 0.06 & 0.24 & 0.17 & 0.02 & 2.76 & 0.21 & 5.41 & 0.00 & 68.14 & 16.46 & 0.00 \\
STB2 & 0.01 & 0.04 & 0.12 & 0.04 & 0.17 & 0.88 & 0.96 & 7.03 & 0.00 & 61.83 & 0.00 & 13.90 \\
STB3 & 0.01 & 0.13 & 0.03 & 0.42 & 12.89 & 0.00 & 0.27 & 6.08 & 12.69 & 51.42 & 9.41 & 0.00 \\
STB4 & 0.01 & 0.08 & 0.03 & 0.04 & 0.07 & 1.66 & 0.32 & 7.13 & 0.00 & 77.98 & 2.42 & 0.00 \\
STB5 & 0.02 & 0.08 & 0.03 & 0.04 & 0.08 & 1.33 & 0.31 & 6.83 & 0.00 & 79.67 & 1.57 & 0.00 \\
\hline
\end{tabular}

Geochemical characteristics and element mobilityGeochemical data for komatiite are highly variable especially with altered komatiite (Sun and Nesbitt, 1978; Nesbitt et. al., 1979 and Arndt, et al., 2008). In order to constrain an origin for the talc bodies of the study variation plots of major oxide and trace elements against $\mathrm{MgO}$ were plotted to examine which oxides of elements or elements were mobile. Figure $5 \mathrm{a}$, a plot of major oxides against magnesia $(\mathrm{MgO})$, revealed good correlation with $\mathrm{Al}_{2} \mathrm{O}_{3}\left(\mathrm{R}^{2}=0.99\right)$ and fairly good correlation with $\mathrm{TiO}_{2}\left(\mathrm{R}^{2}=0.61\right)$. The $\mathrm{Al}_{2} \mathrm{O}_{3} / \mathrm{TiO}_{2}$ ratio preferred over $\mathrm{CaO} / \mathrm{Al}_{2} \mathrm{O}_{3}$ due to mobility of Ca (Arndt et al., 2008) showed values that exceeded the chondritic value of 20 assumed for the Munro komatiite that corresponds to Group II komatiite of Jahn et al. (1982). 
Mg\# values (87.93 - 90.71) (Table 4) suggested an ultramafic source for the talc bodies. $\mathrm{MgO}$ in Archean komatiites is believed not to be mobile (Arndt et al., 2008) while some authors believed it is gained (de Wit et al, 1983; Parman et al., 1997, 2001). Bivariate plot of $\mathrm{CaO} / \mathrm{Al}_{2} \mathrm{O}_{3}$ vs $\mathrm{Mg \#}$ illustrated most samples followed the olivine trend with low values of $\mathrm{CaO} / \mathrm{Al}_{2} \mathrm{O}_{3}$ (Fig. 5b).
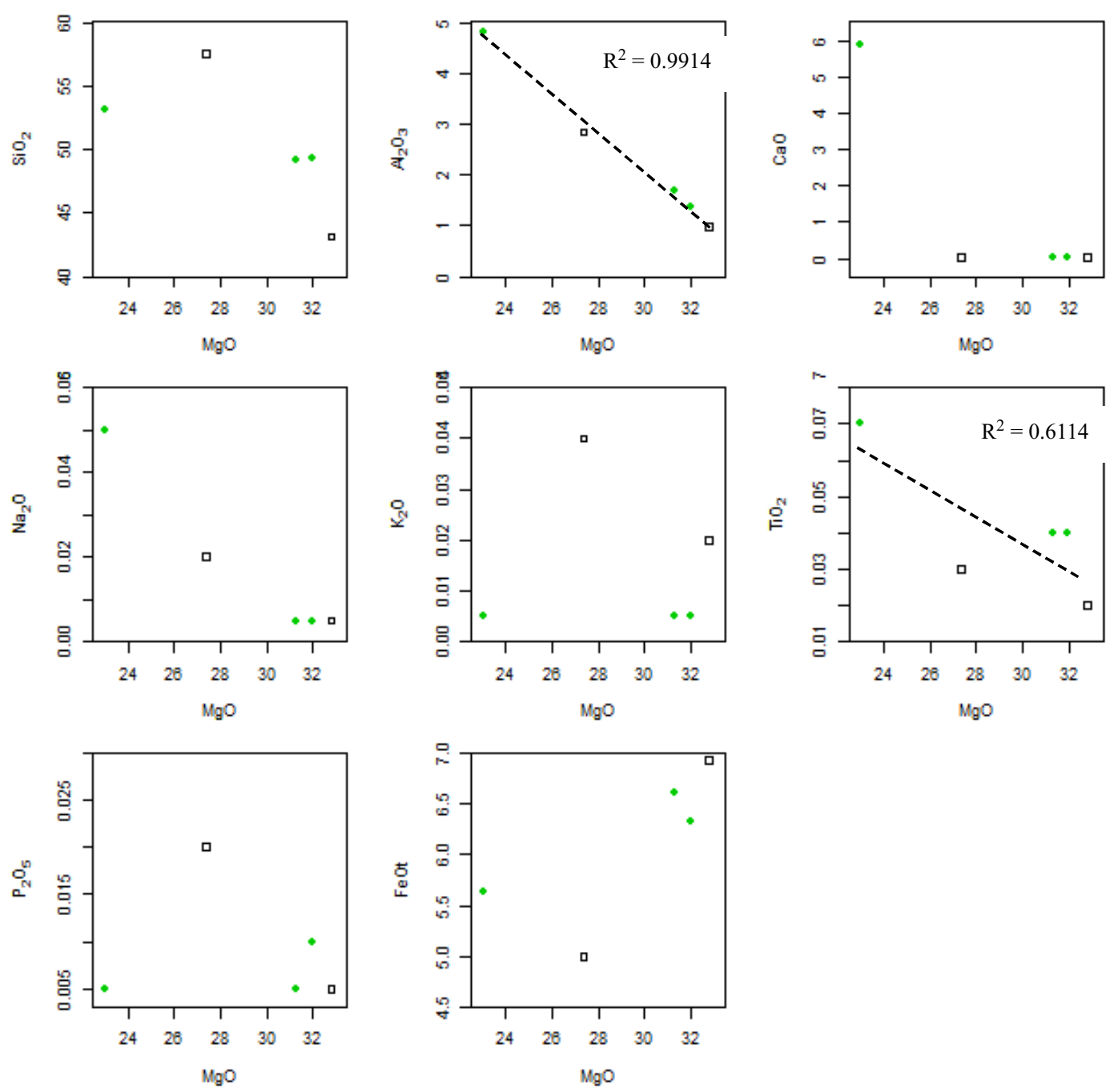

Figure 5a: Major oxide vs $\mathrm{MgO}$ plots revealed good correlation in $\mathrm{Al}_{2} \mathrm{O}_{3}$ vs $\mathrm{MgO}$ and $\mathrm{TiO}_{2}$ vs $\mathrm{MgO}$. 
Afolabi et al.: Understanding Precambrian Komatiite Petrochemistry
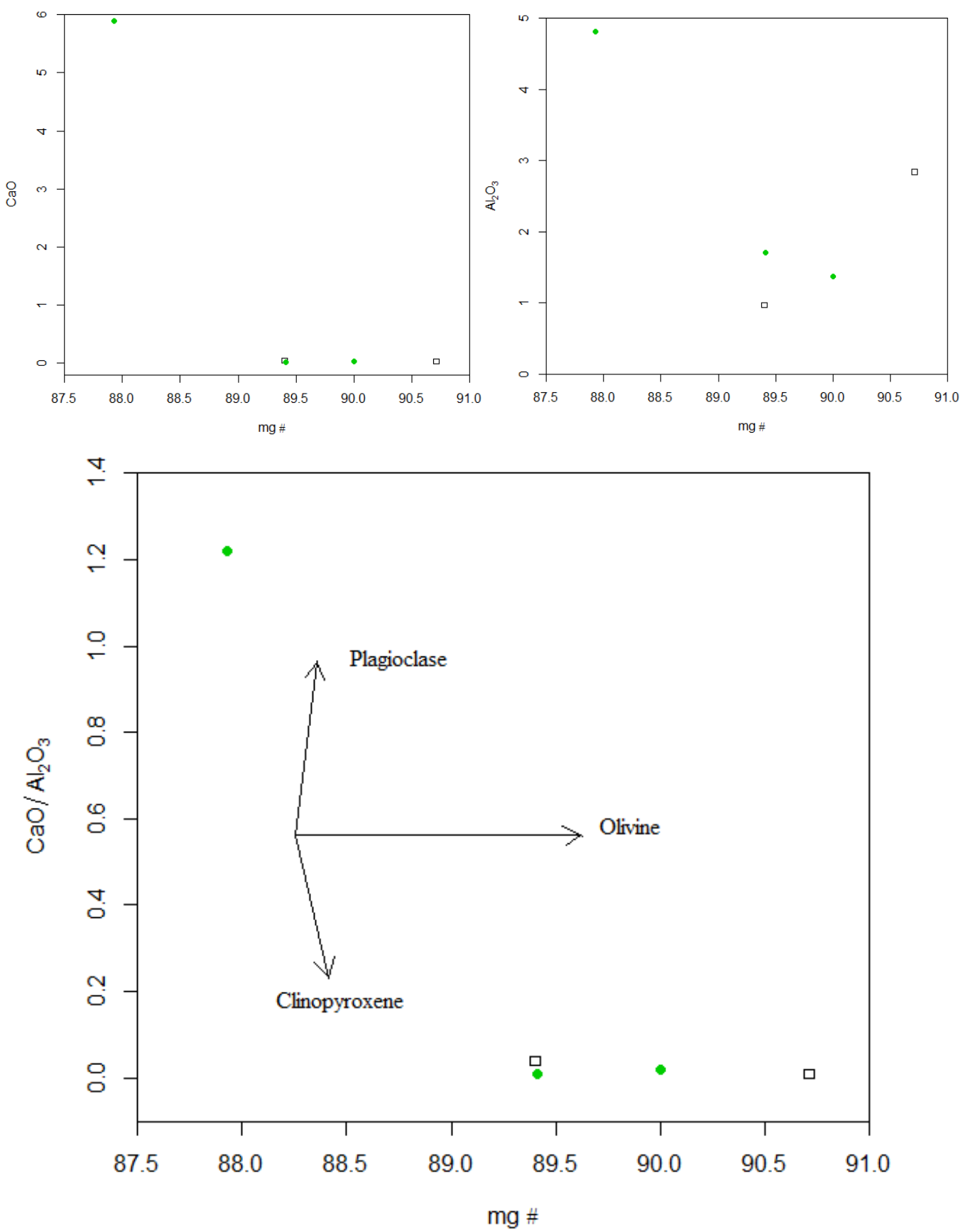

Figure 5b. Bivariate plot of $\mathrm{CaO} / \mathrm{Al}_{2} \mathrm{O}_{3} \mathrm{vs} \mathrm{Mg} \#$ illustrates most samples followed the olivine trend with low values of $\mathrm{CaO} / \mathrm{Al}_{2} \mathrm{O}_{3}$.

\section{Petrogenesis}

The origin of talc bodies have been linked with ultrabasic magmatism. $\mathrm{Co}, \mathrm{V}$ and $\mathrm{Ni}$ vs $\mathrm{MgO}$ showed good correlations (Fig. 5c). This tested the immobility of the trace elements. The nature of the origin was investigated from the plot of $\mathrm{V}-\mathrm{Ni}$ Th*10 (Bracciali et al., 2007) and samples plotted within and around the ultramafic rock region (Fig. 6). The use of $\mathrm{V}$ and $\mathrm{Ni}$ is plausible since the plots of $\mathrm{V}$ and $\mathrm{Ni}$ vs $\mathrm{MgO}$ proved that these elements were immobile. This evidence supported $\mathrm{Mg} \#$ values above 80 observed for this study. $\mathrm{Fe} / \mathrm{Fe}+\mathrm{Mg}$ ratio of these meta-ultramafites ranged from 0.169 to 0.214 with average value of 0.19. The plot of $\mathrm{Al}_{2} \mathrm{O}_{3}$ vs $\mathrm{Fe}_{2} \mathrm{O}_{3} /\left(\mathrm{Fe}_{2} \mathrm{O}_{3}+\mathrm{MgO}\right)$ (after Arndt et al., 1977) (Fig. 7a) showed samples plotted well in the Komatiitic field with possible thoeliitic character for the parent magma. Nesbitt et al., (1979) suggested komatiite from Barberton, South Africa, as having two distinct compositions: basaltic and peridotitic komatiites. The metaultramafite is shown as not having basaltic 
compositions. Trilinear plot of $\mathrm{Al}-\mathrm{Fe}^{\mathrm{T}}+\mathrm{Ti}-\mathrm{Mg}$ (Jensen, 1976) (Fig. 7b) defined a komatiite parentage without basaltic composition for the Talc bodies of the study. The nature of the magma type of these lenticular bodies presumed to be of primitive or primary magmatism based on the Irvine and Baragar (1971) AFM plot (Fig. 7c) where the samples plotted towards the magnesian end was revealed.

Total alkali vs silica (TAS) plot (Fig. 8a) modified by Le Bas et al., (2000) to discriminate high magnesian rocks $(>18 \% \mathrm{MgO})$ classified the talc bodies of the study as komatiite with $\mathrm{MgO}>18 \%$ and $\mathrm{TiO}_{2}<1 \%$. Talc bodies of the study were differentiated from meimechite and boninite which are closely related. Plot of molar ratio of $\mathrm{TiO}_{2} \mathrm{vs} \mathrm{Al}_{2} \mathrm{O}_{3}$ (modified after Hanski et al., 2001) revealed samples plotting from Al-undepleted komatiite field towards the origin (Fig. 8b). The trend illustrated may be linked with possible metamorphic alterations of komatiite to talc rich bodies (talc schist). Plot of $\mathrm{Gd} / \mathrm{Yb}$ vs $\mathrm{Al}_{2} \mathrm{O}_{3} / \mathrm{TiO}_{2}$ (after Hoffman, 1988) (Fig. 8c) illustrated samples shared characteristics similar to Jahn et. al.,'s (1982) Group III komatiite. All samples satisfied the $\mathrm{Al}_{2} \mathrm{O}_{3} / \mathrm{TiO}_{2}>20$ chondritic value, $\mathrm{Gd} / \mathrm{Yb}<1$ and $\mathrm{CaO} / \mathrm{Al}_{2} \mathrm{O}_{3}<1$ requirement in order to be classified as Group III. 
Afolabi et al.: Understanding Precambrian Komatiite Petrochemistry
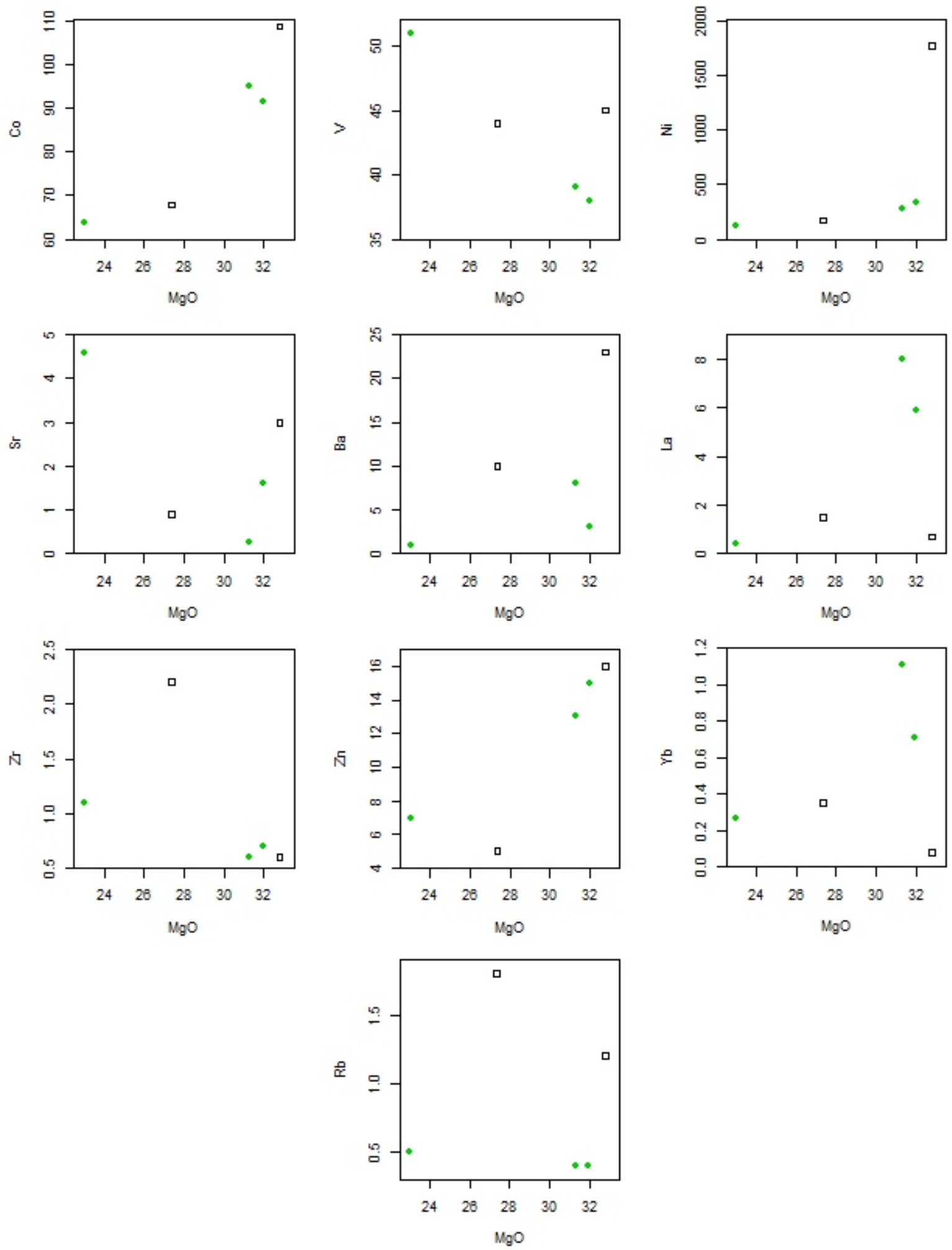

Figure $5 \mathrm{c}: \mathrm{MgO}$ vs trace elements showed linear trends for some compatible elements. $\mathrm{Ni}\left(\mathrm{R}^{2}=0.33\right), \mathrm{V}\left(\mathrm{R}^{2}=\right.$ 0.611), $\mathrm{Zn}\left(\mathrm{R}^{2}=0.7373\right)$ and $\mathrm{Co}\left(\mathrm{R}^{2}=0.855\right)$ showed good correlation with immobile MgO suggesting immobility. 


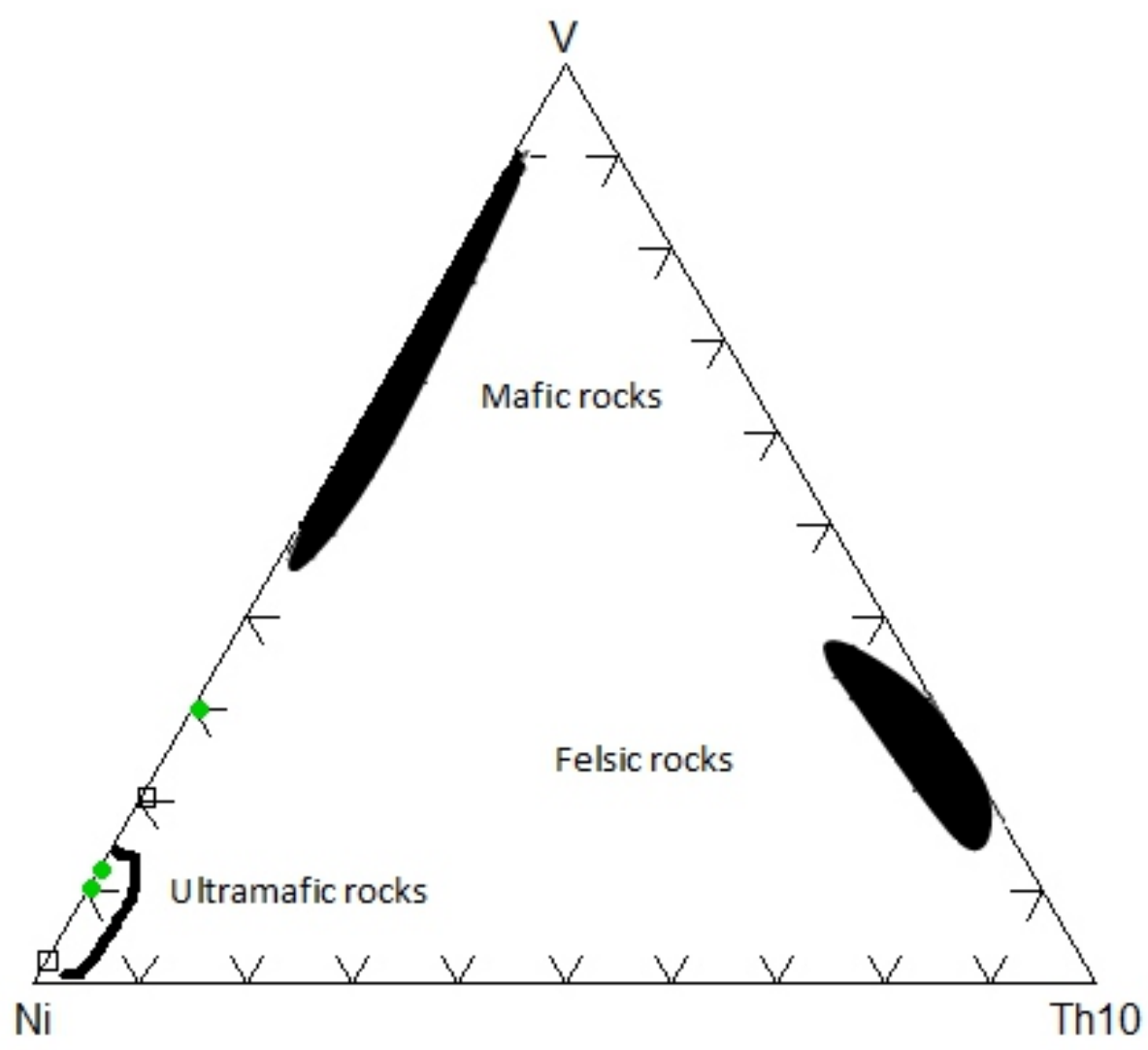

Figure 6: V-Ni-Th*10 Ternary Plot of Bracciali et al. (2007) of Samples Plotting within and around the Ultramafic Rock Region.
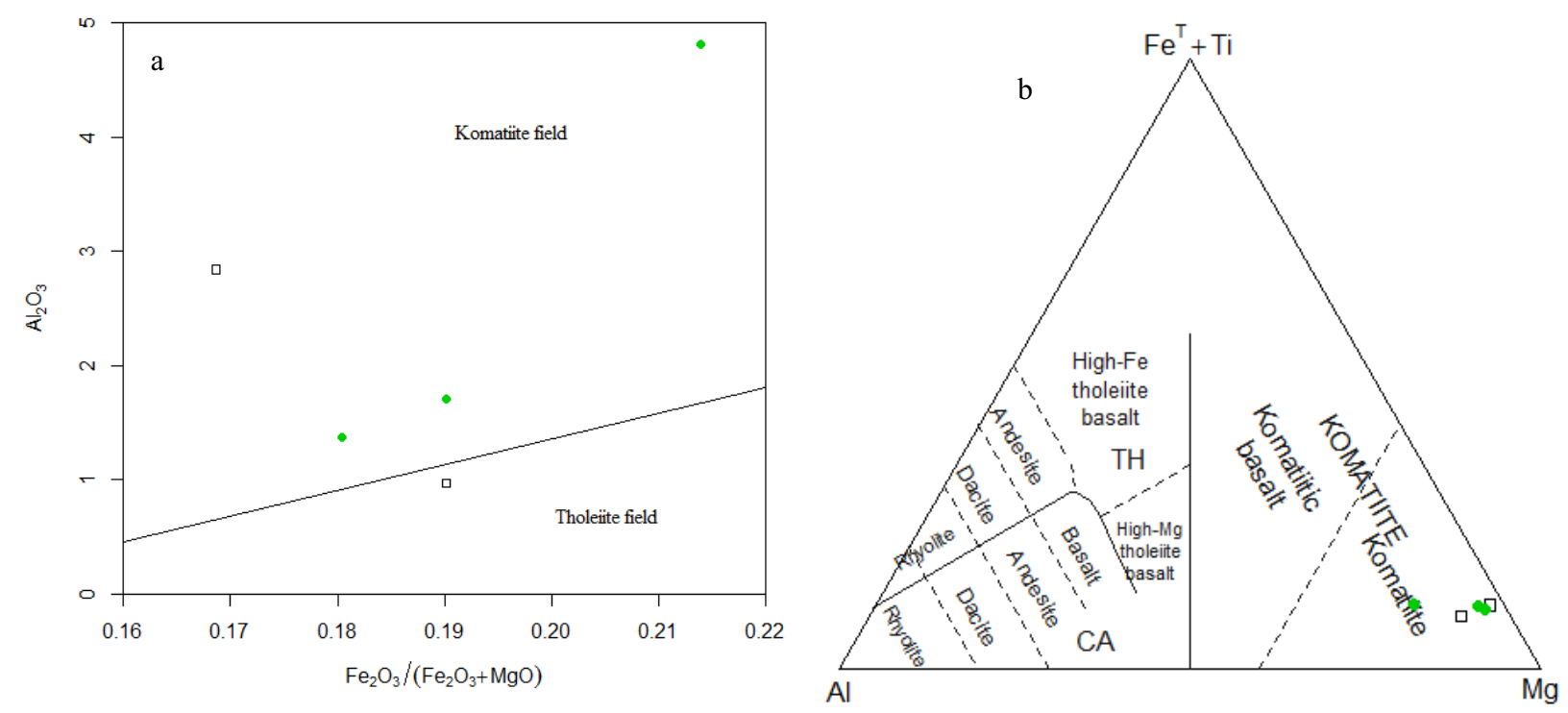

Figure 7: a) Plot of $\mathrm{Al}_{2} \mathrm{O}_{3} / \mathrm{Fe}_{2} \mathrm{O}_{3}\left(\mathrm{Fe}_{2} \mathrm{O}_{3}+\mathrm{MgO}\right.$ ) (Arndt et al., 1977) models a Komatiitic origin for the talc bodies. Sample STB2 falls just into the tholeiitic field. b) Trilinear plot of Al-Fe+Ti_Mg of Jensen (1976) displayed a Komatiitic origin for the Talc body. 


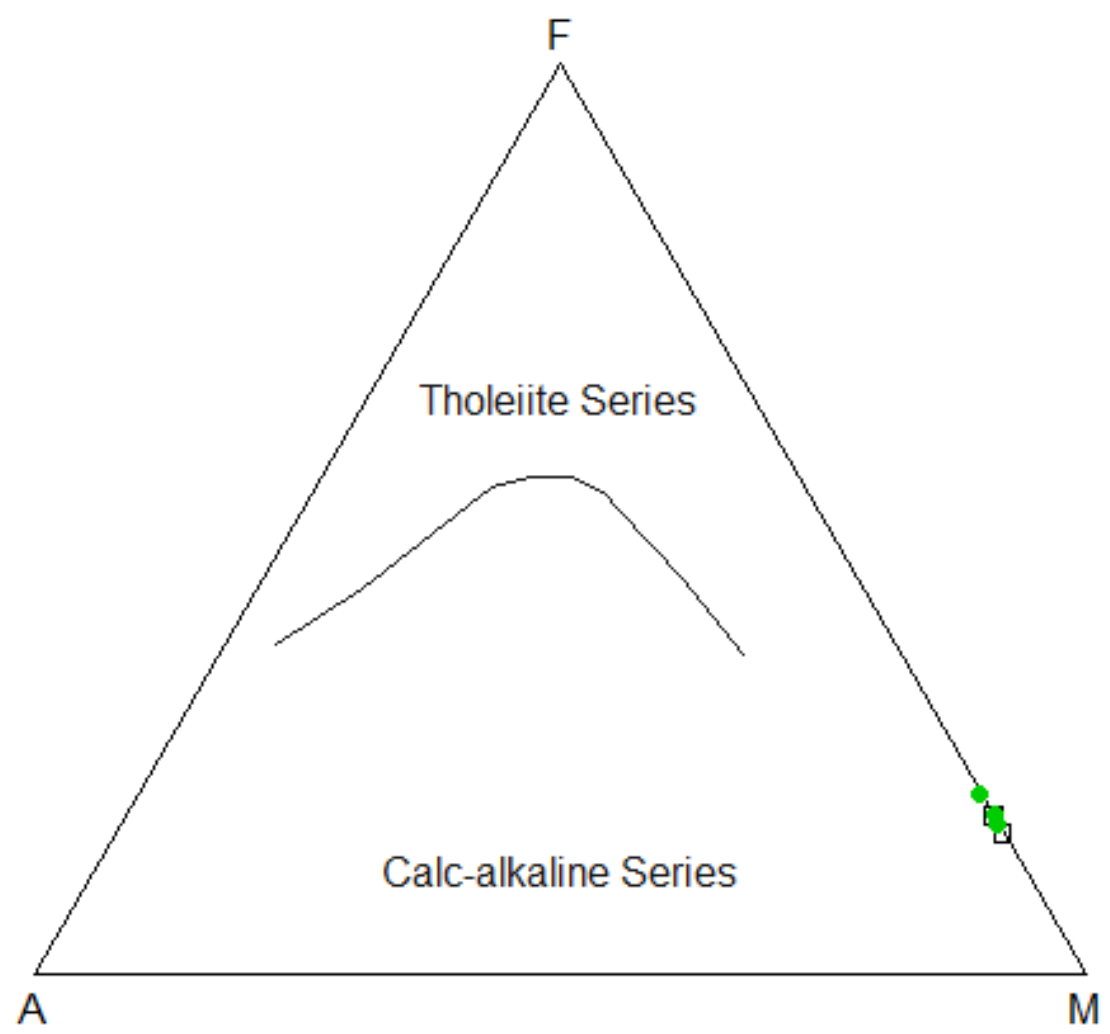

Figure 7c: AFM plot (after Irvine and Baragar, 1971) defines unfractionated ultramafites of calc-alkaline origin.

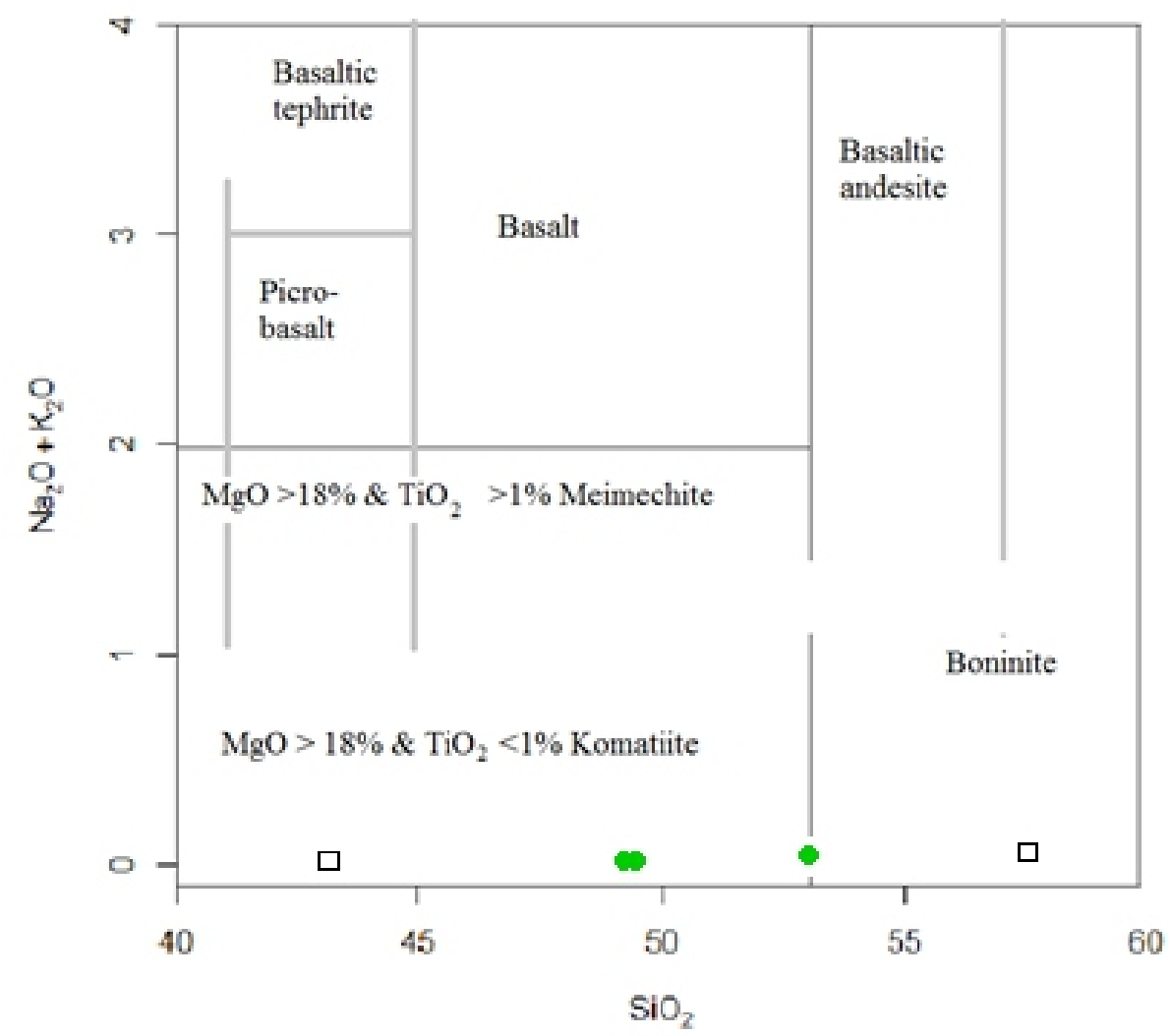

Figure 8a. Total Alkali vs Silica plot after Le Bas et al., (2000) illustrates Komatiitic origin with chemical variation towards Boninite chemical character. The chemical variation may be due to mantle heterogeneity or thermal erosion. 
Afolabi et al.: Understanding Precambrian Komatiite Petrochemistry

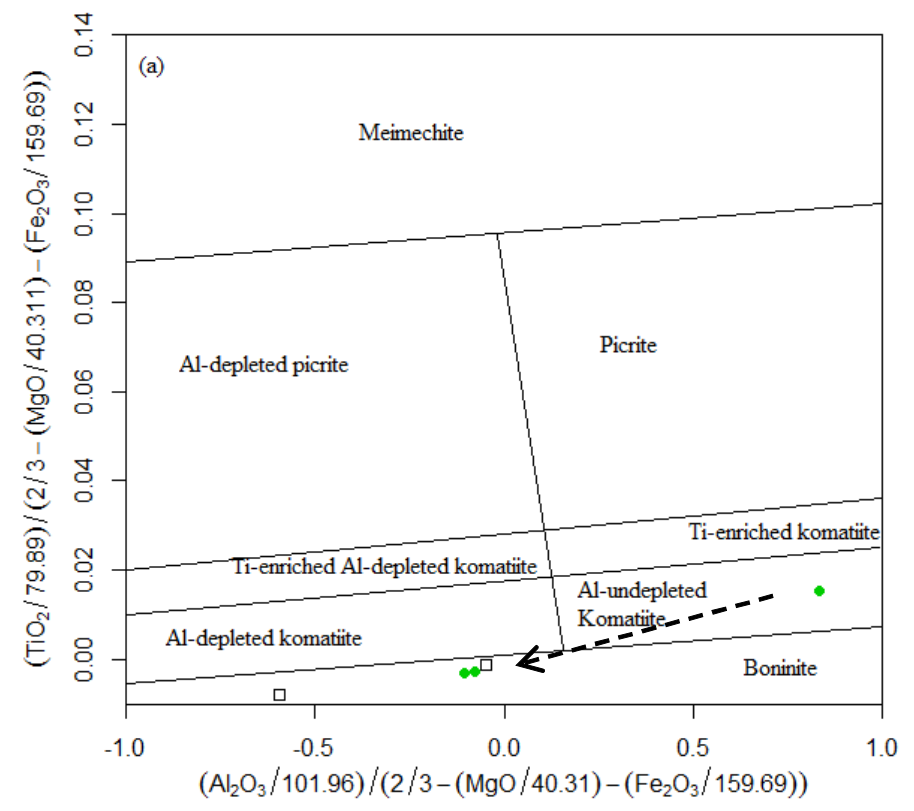

Figure 8b. Plot of molar ratio of $\mathrm{TiO}_{2} \mathrm{vs}_{2} \mathrm{Al}_{3}$ (modified after Hanski et al., 2001).

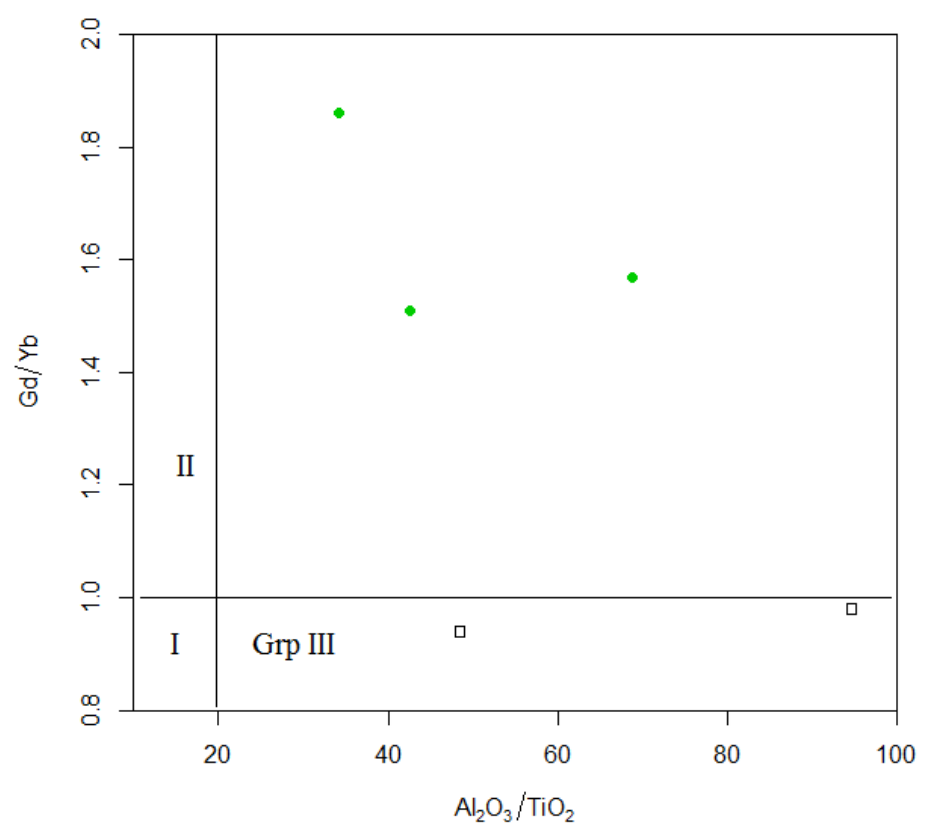

Figure 8c. Plot of $\mathrm{Gd} / \mathrm{Yb}$ vs $\mathrm{Al}_{2} \mathrm{O}_{3} / \mathrm{TiO}_{2}$ (Hoffman, 1988).

Plot of Ti vs V (Fig. 9) (after Shervais, 1982) revealed arc environment for the Talc bodies. Probable Island Arc Basalt (IAB) may be connected with differentiation of the primary magma of the ultramafic composition by partial melting processes.

Rare earth element plot (Fig. 10) based on Primitive mantle normalization revealed near flat pattern with slight LREE enrichment for samples collected at Kajola, near the ISZ, found in association with quartz mica schist and augen gneiss (STB1 and 2) and a flat pattern for samples collected at Ilua, further west of the ISZ, in close association with quartzitic schist (STB3, 4 and 5). Variable Eu anomaly is observed for the Ilua samples (STB3, 4 and 5) with STB3 showing positive $\mathrm{Eu}$ anomaly. Again variation may be linked with hydrothermal alteration or metasomatism rather than plagioclase fractionation as ultramafites are lacking in this (Arndtet.al., 2008). 
Trace element normalised to Primitive mantle (after McDonough and Sun, 1995) revealed mobility for Rb, Ba, Nb, Sr, Zr and the HREE (Fig. 11a) linked to alteration by hydrothermal fluid or metamorphism. Chondrite normalisation (after Sun et. al., 1980) revealed the talc bodies are slightly enriched in trace element above chondrite values (Fig. 11b). Elemental ratios of REE showed variable LREE enrichment with $\mathrm{La} / \mathrm{Yb}$ values ranging from $1-6$ for all samples. Ce/Sm ratio values tend to discriminate the samples. Samples close to the shear zone (STB1 and 2) showed Ce/Sm (LREE/MREE) values $>1$ while those farther away had values $<1$. Dy/Yb representing MREE/HREE revealed values $<1$ for samples STB1 and 2 close to ISZ while samples farther west of the ISZ had values $>1$ (Table 4).

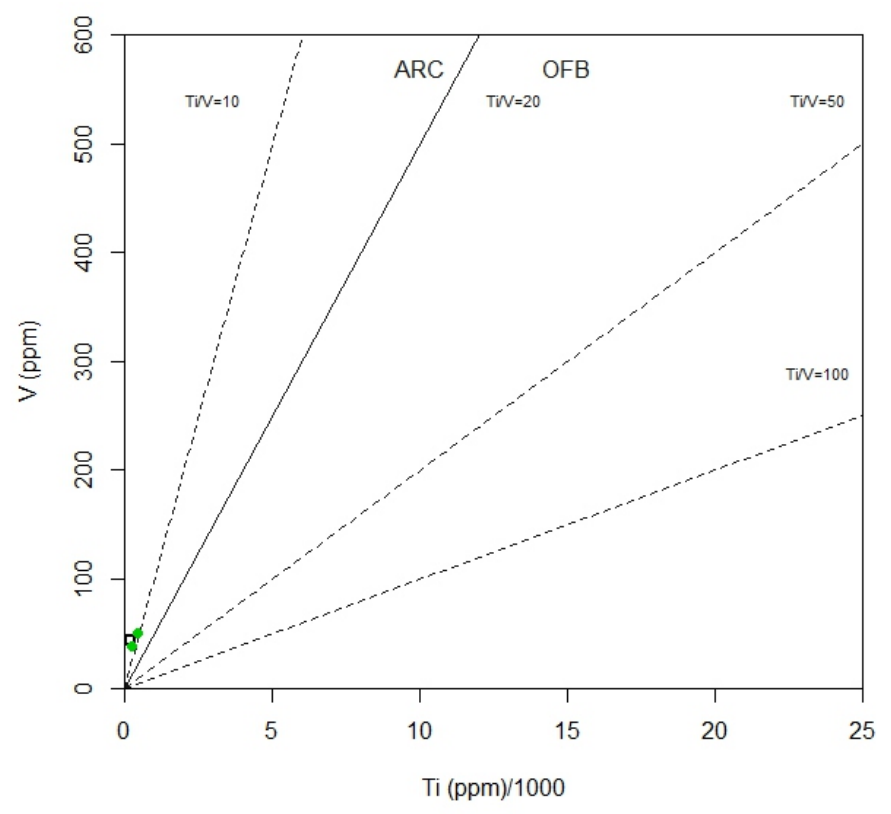

Figure 9: Plot of V vs Ti (after Shervais, 1982) showed the samples plotted in the arc environment.

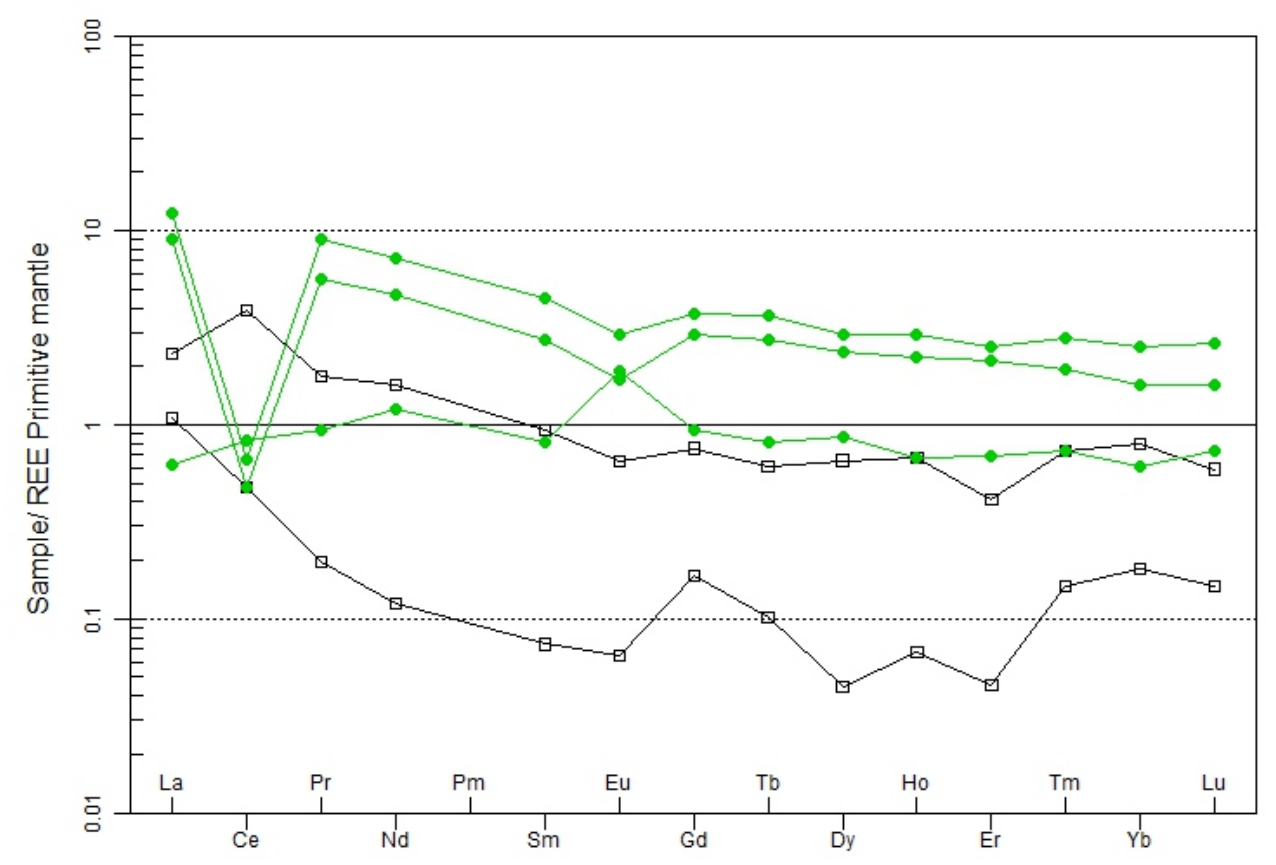

Figure 10. Rare earth element values normalised to Primitive mantle (after McDonough and Sun, 1995) showed relatively flat REE pattern. The REEs appear to be largely immobile except for Ce and Eu attributed to mobility most probably during metamorphism. 
Afolabi et al.: Understanding Precambrian Komatiite Petrochemistry

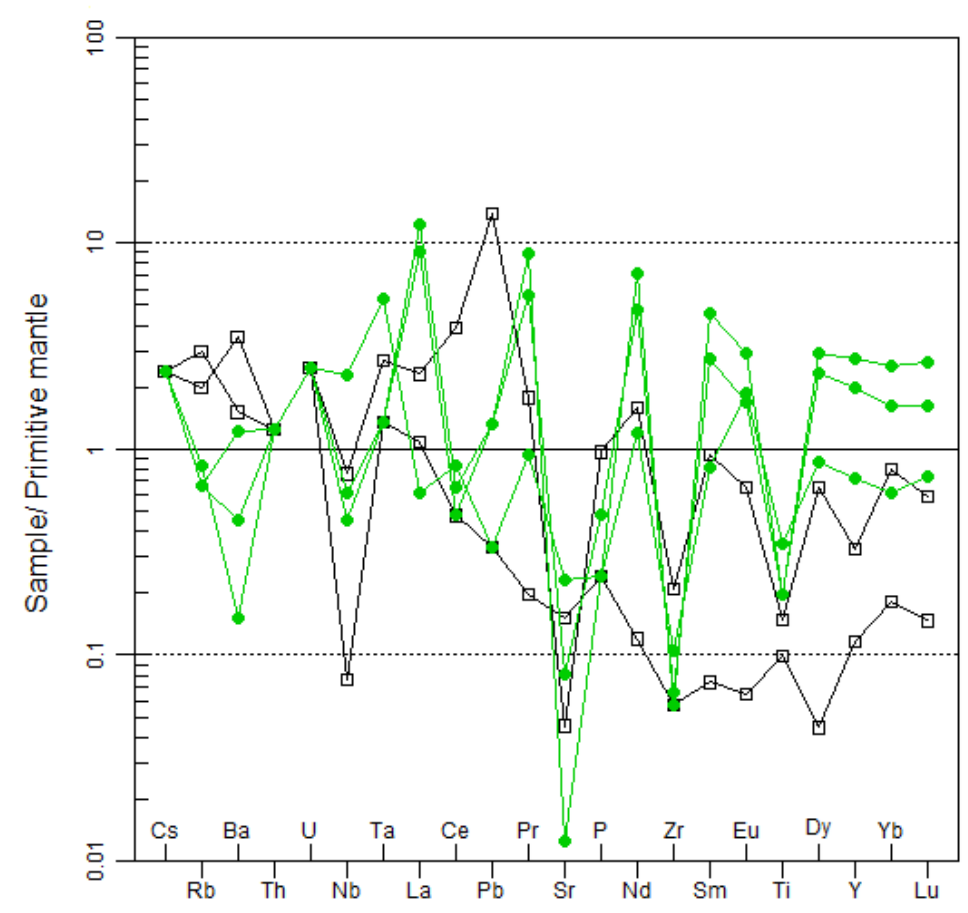

Figure 11a: Trace element normalised to Primitive mantle (after McDonough and Sun, 1995) revealed mobility for $\mathrm{Rb}, \mathrm{Ba}, \mathrm{Nb}, \mathrm{Sr}, \mathrm{Zr}$ and the HREE.

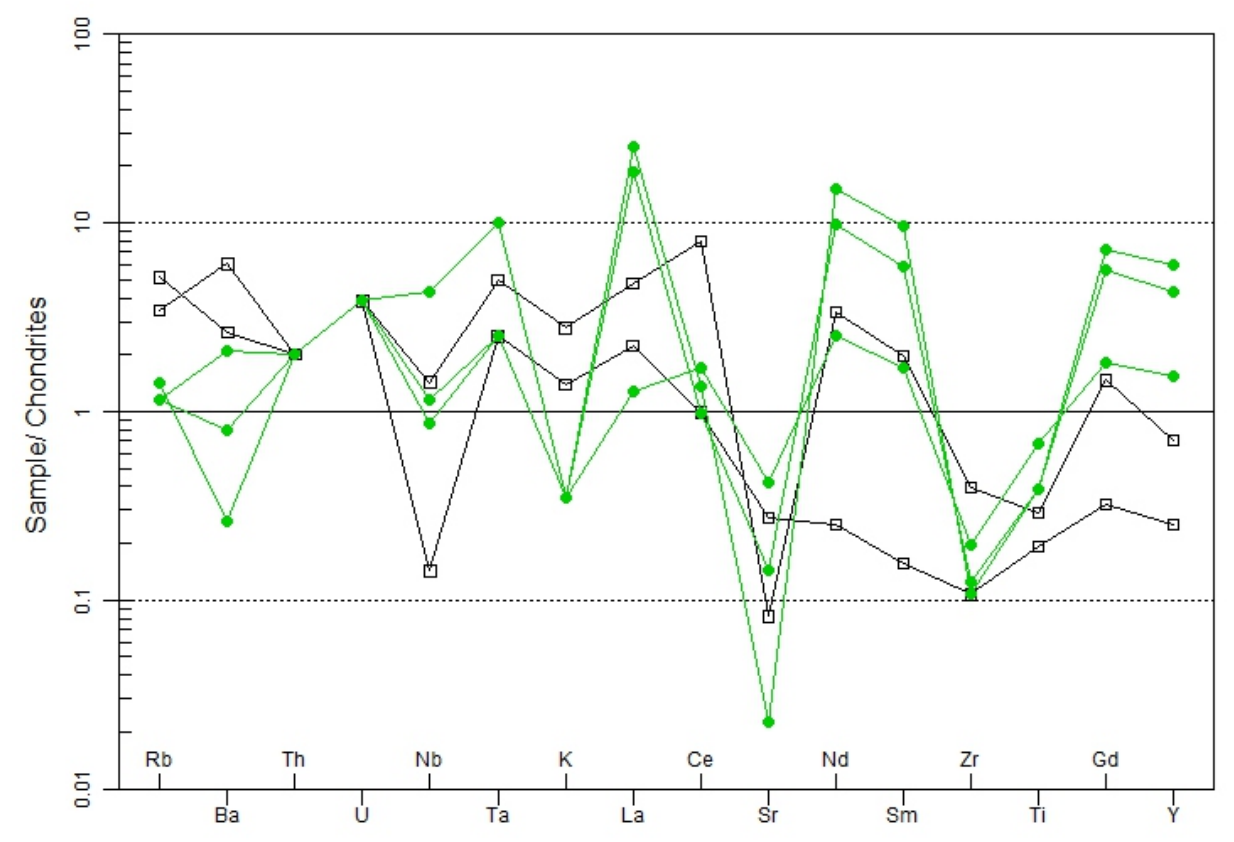

Figure 11b. Chondrite normalised plot after Sun et. al., (1980) revealed the talc bodies are slightly enriched in trace element above chondrite values. 


\section{CONCLUSION}

Talc bodies were found to occur at two sites west of the Ifewara Shear Zone (ISZ). Outcrops at Ilua south of the granite pluton were exposed in close proximity to quartzitic schists while talc body at Kajola within close vicinity of the ISZ north-east of Ilua occurred within quartz schist, quartzite and augen gneiss.

Serpentine, resister olivine with possible alteration to pyroxene, talc and tremolite were observed from thin section slides. Hydrothermal alterations of olivine crystals formed skeletal serpentine interpreted as relic olivine crystals. Normative olivine was observed for one of the studied samples while all samples showed normative hypersthene.

$\mathrm{MgO}$ values above $18 \%$ and $\mathrm{Mg} \#>80$ inferred a possible ultramafic magma parentage. Geochemical data further suggests that the talc bodies of possible ultramafic primary magma parentage could be linked to primary komatiitic magma. Plot of Al-Fe+Ti_Mg illustrated komatiitic magma as probable parent magma for the talc bodies. A komatiite comparison was attempted. $\mathrm{Al}_{2} \mathrm{O}_{3} / \mathrm{TiO}_{2}, \mathrm{Gd} / \mathrm{Yb}(\mathrm{N})$ ratios and HREE were used to classify the meta-ultramafite. $\mathrm{Al}_{2} \mathrm{O}_{3} / \mathrm{TiO}_{2}$ values averaged 58 above chondritic value of $20 . \mathrm{Gd} / \mathrm{Yb}(\mathrm{N})$ ratios showing $<1$ for samples close to ISZ and $>1$ for samples farther from the ISZ and $\mathrm{CaO} / \mathrm{Al}_{2} \mathrm{O}_{3}$ values averaging $0.26(<1)$ compared with of Jahn et al.'s (1982) Group III classification. Flat HREE was observed, however, variable $\mathrm{Ce} / \mathrm{Sm}$ and $\mathrm{Dy} / \mathrm{Yb}$ ratios proved useful in constraining the proximity of the talc bodies like the $\mathrm{Gd} / \mathrm{Yb}(\mathrm{N})$ ratios did.

\section{REFERENCE}

Afolabi, O. A., 2017. Geological mapping and geochemical characterisation of lithological units in part of Sheet 243, Ilesha, Southwestern Nigeria. Unpubl Ph. D. Thesis, University of Ibadan, Ibadan. 462P.

Akin-Ojo, O. A., 1992. Compositional and Industrial studies of talc bodies in the Precambrian domain of southwestern Nigeria. Unpubl. Ph.D thesis, University of Ibadan, Ibadan, Nigeria. 215p.

Arndt, N., 2003. Komatiites, kimberlites, and boninites. Journal of Geophysical Research 108, 2293.

Arndt, N. T., Naldrett, A. J. and Pyke, D. R. 1977. Komatiitic and iron-rich tholeiitic lavas of Munro Township, northeast Ontario. Journal of Petrology, 18, 319-369.

Arndt, N., Lesher, C. M. and Barnes, S. J., 2008. Komatiite. Cambridge University Press, USA. 487 P.

Bolarinwa, A. T. and Adeleye, M. A., 2015. Nature and Origin of the Amphibolites in the Precambrian Basement Complex of Iseyin and Ilesha Schist Belts, Southwestern Nigeria. Journal of Geography and Geology, Vol. 7 (2): 6 - 17 pp.

Boynton, W. V., 1984. Geochemistry of the Rare Earth Elements: meteorite studies. In: P. Henderson (ed.), Rare Earth Element Geochemistry, Elsevier: 63-114 pp.

Bracciali, L., Marroni, M., Pandolfi, L. and Rocchi, S., 2007. Geochemistry and petrography of Western Tethys Cretaceous sedimentary covers (Corsica and Northern Apennines): from source areas to configuration of margins. In: J. Arribas, S. Cretelli, and M. J. Johnson (Eds.) Sedimentary Provenance and Petrogenesis: Perspective for Petrography and Geochemistry. Geological Society of American Special Paper 420: 73-93 pp.

Caby, R., 1989. Precambrian terranes of BeninNigeria and northeast Brazil and the Late Proterozoic South Atlantic fit. Geological Society of America. 145-158 pp.

Dada, S. S., 2015. Proterozoic evolution of the Nigerian-Boborema province. Pankhurst, R. J., Trouw, R. A. J., Brito Neves, B. B. and De Wit, M. J. (eds) - West Gondwana: PreCenozoic correlations across the South Atlantic Region. Geological Society, London, Special Publications, 294, 121 $136 \mathrm{pp}$.

Desmarais, N., 1981. Precambrian metamorphic rocks in the Ruby Range, Montana: Precambrian Research 16, p. 67-101.

de Wit, M. J., Hart, R., Pyle, D. (1983) Mgmetasomatism of the oceanic crust; Implications for the formation of ultramafic rock types. EOS (Transactions, American Geophysical Union), 64, 333. 
El-Sharkawy, M. F., 2000. Talc mineralization of ultramafic affinity in the Eastern Desert of Egypt. Mineralium Deposita, SpringerVerlag, 35: 346-363.

Elueze, A. A. and Akin-Ojo, O. A., 1993. Functional characterisation of talc bodies in southwestern Nigeria. Mineral Wealth, $85,7-14 \mathrm{pp}$.

Elueze, A. A., 1981. Petrographic studies of metabasic rocks and meta-ultramafites in relations to mineralisation in Nigerian schist belt. Journal of Mining and Geology, 18(1), 31-36 pp.

Elueze, A. A., 1988. Geology of the Precambrian Schist belt in Ilesha area Southwestern Nigeria. In Oluyide P. O. (Ed.) Precambrian Geology of Nigeria, Geological Survey of Nigeria Publication: $77-82 \mathrm{pp}$.

Gopta, A. K., 2007. Petrology and genesis of Igneous rocks. Narosa Publ. House, 22 Daryaganj, Delhi Medical Association Road, New Delhi 110 002.479p.

Grove, T. L., Parman, S. W. and Dann, J. C., 1999. Conditions of magma generation for Archean komatiites from the Barberton mountainland South Africa. In: F. Yingwei, C. M. Bertka and B. O. Mysen. (eds). Mantle Petrology: Field observations and high pressure experimentation. The Geochemical Society. No. 6.155-167 pp.

Hanski, E., Huhma, H., Rastas, P. and Kamenetsky, V. S., 2001. The Palaeoproterozoic komatiite-picrite association of Finnish Lapland. Journal of Petrology 42 (5), 855-876 pp.

Hofmann, A. W., 1988. Chemical differentiation of the Earth: the relationship between mantle, continental crust, and oceanic crust. Earth and Planetary Science Letters, 90, 297-314 pp.

Irvine, T. N. and Baragar, W. R. A., 1971. A guide to the chemical classification of the common volcanic rocks. Canadian Journal of Earth Sciences 8, 523-548 pp.

Jahn, B.-M., Gruau, G., Glickson, A. Y., 1982. Komatiites of the Onverwacht Group, South Africa: REE chemistry, $\mathrm{Sm}-\mathrm{Nd}$ age and mantle evolution. Contributions to Mineralogy and Petrology, 80, 25-40 pp.
Jensen L. S., 1976. A new cation plot for classifying subalkalic volcanic rocks. Ont Div Mines, Misc Pap 66, 1-21 pp.

Lahaye, Y., Arndt, N. T., Byerly, G., Gruau, G., Fourcade, S., Chauvel, C., 1995. The influence of alteration on the traceelement and $\mathrm{Nd}$ isotope compositions of komatiites. Chemical Geology, 126, 43-64.

Le Bas, M. J., 2000. IUGS reclassification of the high-Mg and picritic volcanic rocks. Journal of Petrology, 41, 1467-1470.

McDonough, W. F. and Sun, S., 1995. The composition of the Earth. Elsevier. Chemical Geology, 120.223-253 pp.

Nesbitt, R. W., Sun, S. S., 1976. Geochemistry of Archaean spinifex-textured peridotites and magnesian and low-magnesian tholeiites. Earth and Planetary Science Letters, 31, 433-453 pp.

Nesbitt, R. W., Sun, S. S., Purvis, A. C., 1979. Komatiites: geochemistry and genesis. Canadian Mineralogist, 17, 165-186 pp.

Olobaniyi, S. B. and Mucke, A. 2011. Chemical composition of chromite and intergrown chlorite in metamorphosed ultramafic rocks (serpentinite and talc schist) of the Egbe-Isanlu schist belt, southwest Nigeria: genetic implications. Jour. of Min. and Geol. Vol. 47 (2). 115-134 pp.

Parman, S., Dann, J., Grove, T. L., de Wit, M. J. (1997) Emplacement conditions of komatiite magmas from the $3.49 \mathrm{Ga}$ Komati Formation, Barberton Greenstone Belt, South Africa. Earth and Planetary Science Letters, 150, 303-323 pp.

Parman, S., Grove, T. L., Dann, J. (2001) The production of Barberton komatiites in an Archean subduction zone. Geophysical Research Letters, 28, 2513-2516 pp.

Rahaman, M. A., 1976. Review of basement geology of Southwestern Nigeria. In: C. A. Kogbe (ed.), Geology of Nigeria, Elizabethan, Lagos, Nigeria: $41-57$ pp.

Rudnick, R. L. and Gao, S., 2003. Composition of the continental crust. In: A. M. Davis, H. D. Holland and K. K. Turekian (Eds), Treatise on Geochemistry. Elsevier Ltd, vol 3,1-64.

Sossi, P. A., Eggins, S. M., Nesbitt, R. W., Nebel, 
O., Hergt, J. M., Campbell, I. H., O'Neil, Shervais, J. W., 1982. Ti-V plots and the H. St. C., Kranendonk, M. V. and Davies, D. R., 2016. Petrogensis and geochemistry of Archean Komatiites. Journal of Petrology, Vol. 57, Issue 1, 147-184pp.

Sun, S. S. and Nesbitt, R. W., 1978. Petrogenesis of Archean ultrabasic and basic volcanics: evidence from rare earth elements. Contributions to Mineralogy and Petrology, 65, 301-325.

Sun, S. S., Bailey, D. K., Tarney J. and Dunham, K., 1980. Lead isotopic study of young volcanic rocks from mid-ocean ridges, ocean islands and island arcs. Philos Trans R Soc London A297: 409-445 pp. petrogenesis of modern and ophiolitic lavas. Earth and Planetary Science Letters, Elsevier Scientific Publishing Company, Amsterdam, 59.101-118 pp.

Viljoen, M. J. and Viljoen, R. P., 1969b. Evidence for the existence of a mobile extrusive peridotitic magma from the Komati Formation of the Onverwacht Group. Geological Society of South Africa, Special Publication, 21, 87-112.

Viljoen, R. P. and Viljoen M. J., 1982. Komatiites an historical review. In: N. T. Arndt and E. G. Nisbet (eds.) Komatiites. London: George Allen and Unwin. pp. 5-18. 